\title{
Can We Regulate Our Way to Energy Efficiency? Product Standards as Climate Policy
}

\author{
Noah M. Sachs*
}

INTRODUCTION 1632

I. A REgUlatory StRATEgY FOR THE Climate ............... 1636

A. Product Standards-Objectives and

Regulatory Design.... 1637

B. Standards in Practice: The United States and the European Union. 1642

1. Efficiency Regulation in the United States 1642

2. Efficiency Regulation in the European Union 1646

II. Comparing Product Regulation to Alternative CLIMATE POLICIES............................................... 1650

A. Energy Market Failures and Barriers ................ 1650

B. Standards Versus a Labeling-Only Strategy for Efficiency ........................................... 1654

C. Standards Versus an Energy-Pricing Strategy for Efficiency ............................................. 1656

D. Avoiding the Pitfalls of Regulation ................... 1660

III. THE TASK AHEAD ............................................. 1667

A. The Future Technical Potential for Product

Standards ................................................. 1667

B. The Political Viability of Product Standards....... 1670

* Professor, University of Richmond School of Law and Director, Robert R. Merhige, Jr. Center for Environmental Studies. In February 2012, this paper was presented at a faculty colloquy at Wake Forest University and at a conference at Vanderbilt University Law SchoolSupply and Demand: Barriers to a New Energy Future. The editors of the Vanderbilt Law Review did a superb job in organizing the conference and made numerous suggestions for improving initial drafts. Thanks also to Professors John Dernbach and Jim Gibson, who provided helpful comments on drafts, and to Eric Wallace for invaluable research assistance. 


\section{INTRODUCTION}

Alternative energy supplies get most of the attention in the climate change debate, but reducing energy demand should be the dominant strategy for cutting global greenhouse gas emissions. Dozens of technical studies have concluded that improving the efficiency of automobiles, furnaces, motors, consumer electronics, lighting, air conditioners, and other energy-using products is the cheapest and fastest way to achieve dramatic reductions in greenhouse gas emissions. ${ }^{1}$ In fact, avoiding catastrophic global heating largely depends on how fast energy efficient technology can be deployed over the next few decades. ${ }^{2}$

Energy efficiency can be promoted through multiple policies, such as energy taxes, a cap-and-trade system, tax credits for efficient appliances, product labeling, increased government research and

1. See, e.g., AMERICA'S ENERGY Future PANEL ON ENERgy EFFiciency TeChS., NAT'L ACAD. OF SCIS., REAL PROSPECTS For ENERGY EFFICIENCY IN THE UNITEd STATES 41-56 (2010) [hereinafter REAL PROSPECTS REPORT] (analyzing the potential for improvements in energy efficiency in lighting, air conditioning, and other appliances in residential and commercial buildings); AMORY B. LOVINS, ROCKY MOUNTAIN INST., REINVENTING FIRE: BOLD BUSINESS SOLUTIONS FOR THE NEW ENERGY ERA 11-12 (2011) (outlining steps to reduce energy use, modulate demand, and optimize supply in the areas of transportation, buildings, industry, and electricity generation); AM. PHYSICAL SOC'Y, ENERGY=FUTURE: THINK EFFICIENCY 9-14 (2008), available at http://www.aps.org/energyefficiencyreport/report/aps-energyreport.pdf (outlining potential efficiency improvements for transportation, buildings, and industry); FLORIAN Bressand et al., McKinsey Global InST., CuRbing Global Energy Demand Growth: The ENERGY PRODUCTIVITY OPPORTUNITY 17-22 (2007), available at http://www.mckinsey.com /Insights/MGI/Research/Natural_Resources/Curbing_global_energy_demand_growth (outlining cost-effective methods for improving energy productivity); FLORIAN BRESSAND ET AL., MCKINSEY GLOBAL INST., WASTED ENERgY: HOW THE US CAN REACH ITS ENERGY PRODUCTIVITY POTENTIAL 5-15 (2007), available at http://www.mckinsey.com/insights/mgi/research/natural_resources/ how_us_can_reach_its_energy_potential (detailing wasteful energy use in the United States and noting that U.S. energy use per unit of GDP is among the highest in the developed world).

2. According to the 2007 Fourth Assessment Report of the Intergovernmental Panel on Climate Change, the cost of stabilizing greenhouse gas concentrations at $550 \mathrm{ppm}$ by 2050 ranges from $4 \%$ of global GDP (about $0.1 \%$ of global GDP per year) to a slight increase in GDP. See IPCC Fourth Assessment Report: Climate Change 2007, InTERGOVERnMENTAL PANEL ON CLIMATE CHANGE, http://www.ipcc.ch/publications_and_data/ar4/wg3/en/tss3-2-stabilizationscenarios.html (last visited Sept. 22, 2012) (detailing the relationship between the cost of mitigation and long-term stabilization targets in Figure TS.9). This difference in cost projections depends on assumptions made about the rate of technological change and the rate of deployment of low-carbon technology. See id. at fig.TS.10 (estimating cumulative emission reductions for alternative mitigation measures). 
development ("R\&D"), or direct regulatory limits on the energy consumption of products.

Of these policies, the regulatory option seems most intrusive, as it limits consumer choice and requires complex governmental mandates that affect product design. While the other policies nudge consumers in the direction of efficiency, regulation commands energy efficient choices by forcing inefficient products off the market.

In this Article, I demonstrate that the regulatory strategy for energy efficiency is working. Although information disclosure, financial incentives, and other softer alternatives to regulation play a vital role in reducing energy demand, these should be viewed as complements to efficiency regulation, rather than replacements. The regulatory approach has led to substantial cost and energy savings in the past, it has enjoyed bipartisan political support, and it targets products and behaviors that are difficult to address through other policy tools. Given the politics of climate change in the United States, which make federal carbon taxes or a cap-and-trade system infeasible, the regulatory option should be expanded, not abandoned.

The regulatory strategy I focus on in this Article is minimum energy performance standards ("MEPS") for products ${ }^{3}$-efficiency benchmarks that manufacturers must meet to sell products in a jurisdiction. I do not discuss automobile fuel efficiency standards in this Article, as that topic has been amply covered elsewhere. ${ }^{4}$ Most Americans are familiar with MEPS for products other than automobiles because of refrigerator and air conditioner efficiency standards enacted in the 1980 s.

In recent years, governments have dramatically expanded their reliance on MEPS. Beyond refrigeration and air conditioning, governments are now implementing MEPS for dozens of product

3. The International Energy Agency defines MEPS as "legally enforced thresholds for an individual product or group of products, set at a level to exclude a proportion of the worst performing products in the marketplace." MARK ELLIS, INT'L ENERGY AGENCY, EXPERIENCE WITH ENERGY EFFICIENCY REGUL_ATIONS FOR ELECTRICAL EQUIPMENT 18 (2007), available at http://www.iea.org/publications/freepublications/publication/Appliances_Ellis.pdf.

4. See, e.g., COMM. ON THE EFFECTIVENESS \& IMPACT OF CORPORATE AVERAGE FUEL ECONOMY (CAFE) STANDARDS ET AL., NAT'L ACAD. OF SCIS., EFFECTIVENESS AND IMPACT OF CoRPorate AVERAGE FUEL ECONOMY (CAFE) STANDARDS 64-67 (2002) (analyzing environmental and financial impacts of various fuel economy standards); CONG. BUDGET OFFICE, ThE ECONOMic Costs of FUel ECONOMY STANDARDS Versus a Gasoline TAX 16-17 (2003), available at http://www.cbo.gov/sites/default/files/cbofiles/ftpdocs/49xx/doc4917/12-24-03_cafe.pdf (analyzing the effect of raising CAFE standards on gasoline consumption); Jody Freeman, The Obama Administration's National Auto Policy: Lessons from the "Car Deal," 35 HaRV. ENVTL. L. REV. 343, 367-68 (2011) (discussing Obam a Administration initiatives to increase fuel efficiency and reduce automobile greenhouse gas emissions). 
categories, including residential and commercial appliances, consumer electronics, lighting, motors, and other energy-using equipment-all of which have become major contributors to global greenhouse gas emissions. As a result, households are being enlisted as participants in national climate policy.

The international surge in product regulation is a response to rising energy consumption in consumer products and commercial equipment. Consider, for example, residential electrical equipment such as home computers, lighting, and refrigerators. That equipment is responsible for $30 \%$ of all electricity consumed in OECD countries and accounts for $21 \%$ of all energy-related $\mathrm{CO}_{2}$ emissions. ${ }^{5}$ Moreover, the global growth in energy use between now and 2030 just for information and communication technology and consumer electronics will exceed the entire current electricity consumption of the United States and Japan combined. ${ }^{6}$ Energy use is rising globally because affluent households have become voracious consumers of electronic gadgets and conveniences, and the developing world is adopting air conditioning, refrigeration, and information technology at an unprecedented rate.

Given this growth, there is enormous potential for MEPS as a core climate change strategy. By improving the efficiency of energyusing products, governments can avoid construction of hundreds of electricity-generating plants that might otherwise be needed to power all of this equipment. ${ }^{7}$ On a global basis, improving the efficiency of energy-using products in the residential sector alone could abate sixteen quadrillion BTUs of 2020 energy demand-equal to the energy provided by 610 power plants. ${ }^{8}$ In planning a climate change mitigation strategy, we cannot ignore this enormous potential for energy savings. ${ }^{9}$ If we are going to enjoy the fruits of a global economy

5. ELLIS, supra note 3, at 23.

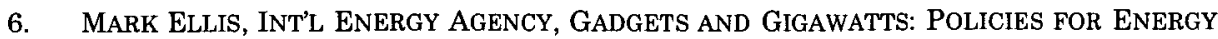
EFFICIENT ELECTRONICS 21 (2009), available at http://www.iea.org/speech/2009/Waide_ GadgetsGigawatts.pdf

7. See, e.g., id. (reporting that $280 \mathrm{GW}$ of new electricity-generating capacity will be needed just to service all the new IT equipment and consumer electronics that will be added to the market between now and 2030).

8. Diana FarRell et al., MCKinsey Global Inst., The Case For INVESTing In Energy PRODUCTIVITY 24 (2008), available at http://www.mckinsey.com/Insights/MGL/Research/Natural_ Resources/The_case_for_investing_in_energy_productivity.

9. See REAL Prospects RePORT, supra note 1, at 1 ("Price fluctuations, national security concerns over U.S. dependence on imported oil, and growing recognition of the need to reduce emissions of greenhouse gases have transformed energy efficiency from an option to a necessity."). 
in 2050 that is predicted to be four times as large as today, ${ }^{10}$ while reducing greenhouse gas emissions $50 \%$ to $85 \%$ below today's levels, ${ }^{11}$ we will need to get substantially more useful work out of every unit of energy consumed.

This Article, one of the first analyses of MEPS in legal scholarship, ${ }^{12}$ discusses the realistic potential for product standards as a climate change strategy. It proceeds in three parts.

In Part I, I introduce the goals and structure of MEPS and then sketch their prior implementation in the United States and the European Union ("EU"). Both the United States and the EU have massively expanded their regulation of product efficiency in the past five years, and efficiency standards are one of the principal environmental legacies of President Obama's first term. The EU has, in addition, deployed other strategies to decrease energy consumption, including high gasoline taxes and its Emissions Trading System. The United States is highly unlikely to enact national emissions trading or carbon taxes any time soon. I argue, therefore, that in the near term direct regulation of the energy use of products is one of the few politically acceptable tools in the U.S. climate toolbox.

In Part II, I provide a theoretical justification for efficiency standards. I argue that standards are an appropriate response to energy market failures and to the environmental externalities inherent in energy consumption. While alternative approaches to

10. See Uri Dadush \& BennetT Stancil, Carnegie Endowment for Int'l Peace, The WORLD ORDER IN 2050, at 8 (2010), available at http://www.carnegieendowment.org/ files/World_Order_in_2050.pdf (noting that the total output of the G20 major economies is expected to grow, in real dollars, from $\$ 38.3$ trillion in 2009 to $\$ 160.0$ trillion in 2050 ).

11. InTERgovernmental Panel on Climate Change, Climate Change 2007: Synthesis REPORT 67 (2007), available at http://www.ipcc.ch/publications_and_data/publications _ipcc_fourth_assessment_report_synthesis_report.htm (projecting that a reduction from year 2000 emissions of $50-85 \%$ by 2050 would keep the global average surface temperature increase to around two degrees Celsius, using "best estimate" climate sensitivity).

12. Economists and political scientists have dominated the academic scholarship on the links between regulation and technological change. See, e.g., Thomas Bernauer et al., Explaining Green Innovation 2 (Ctr. for Int'l \& Comparative Studies, Working Paper No. 17, 2006), available at http://www.cis.ethz.ch/publications/WP_17_GreenInn.pdf. Professor John Dernbach at Widener Law School is one of the few legal scholars to examine MEPS in some detail. See JOHN C. Dernbach, acting as If TOMORRow MatTers: ACcelerating the Transition to SUSTAINABILITY 69 (2012) (arguing that environmental sustainability is consistent with economic and technological growth); John C. Dernbach \& Marianne Tyrell, Federal Energy Efficiency and Conservation Laws, in THE LAW OF ClEAN ENERGY: EFFICIENCY AND RENEWABLeS 25, 26 (Michael Gerrard ed., 2011) (overview of U.S. law and policy governing energy efficiency and conservation); John C. Dernbach, Stabilizing and Then Reducing U.S. Energy Consumption: Legal and Policy Tools for Efficiency and Conservation, 37 ENVTL. L. REP. 10003, 10003-04 (2007). 
climate change mitigation, such as carbon pricing or energy taxes, also address externalities, they are not likely to drive significant changes in energy usage or equipment purchasing decisions. Although these policies will increase energy prices slightly, consumers will either not notice the price increase or will not care enough to change their purchasing decisions and energy-consumption habits. After discussing these hurdles to behavioral and technological change, I then turn to a regulatory strategy. I address some of the traditional criticisms of command-and-control regulation and show why MEPS offer a sound energy efficiency strategy that is consistent with continued product innovation.

Finally, in Part III, I explore the promise and perils of expanding product regulation in the coming years. I outline the potential energy savings that can be expected from feasible product standards, as well as some of the limitations of a regulatory strategy. I also discuss the long-term political viability of MEPS, focusing on the 2011 congressional skirmish over light bulb efficiency standards, which was the first major political backlash in the United States against MEPS. The debate over the light bulb standards pitted energy efficiency against consumer choice, and this values clash, if it continues, could threaten support for efficiency regulation.

\section{A REgUlatory StRATEgy FOR THE Climate}

Government regulation of the energy efficiency of products dates to the 1970s energy crisis. Initially enacted for major household appliances such as refrigerators and air conditioners, MEPS are now applied widely-in the United States, Europe, China, Japan, Australia, and other jurisdictions ${ }^{13}$ - to products such as heating and cooling equipment, lighting, televisions, motors, washers, and fans. MEPS operate by specifying the minimum energy efficiency requirements (or maximum energy usage) for a given product category and forbidding manufacturers from selling products that fall below the standards. In 2009, for example, California enacted a first-in-thenation set of MEPS for televisions, requiring that televisions sold in California use $49 \%$ less energy in 2013 compared to $2009.1^{14}$ This

13. ELLIS, supra note 3, at 29-31.

14. See CAL. Code REGS., tit. $20, \S 1601$ et seq. (2009); News Release, Cal. Energy Comm'n, California Approves New Energy Efficient TV Regulations (Nov. 18, 2009), available at $\mathrm{http} / / / \mathrm{www} . e n e r g y . c a . g o v / r e l e a s e s / 2009$ releases/2009-11-18_tv_regulations.html (discussing the passage and potential results of the California television regulation). 
television regulation, like most MEPS, achieves energy savings by knocking the worst-performing products off the market.

MEPS are in a small class of environmental regulations that target household and business purchasing decisions and energy consumption, rather than harmful emissions from industrial facilities. ${ }^{15}$ They affect common products used in millions of homes, and they touch nearly every corner of the consumer lifestyle. MEPS directly address the carbon emissions from the use of a product, which often exceed the carbon emissions from the production of the product.16 Like twisting a soaking wet towel, governments are attempting to wring out the carbon intensity of products. Below, I outline governmental goals and then discuss the implementation of MEPS in the United States and the EU.

\section{A. Product Standards-Objectives and Regulatory Design}

Governments have three principal goals in enacting MEPS. The first goal is cost savings. Because MEPS reduce long-term operating costs of energy-using equipment, they are widely viewed as a consumer-friendly, cost-effective means of reducing greenhouse gas emissions. ${ }^{17}$ The reduced operational costs more than offset increases

15. Recent environmental scholarship is beginning to address the environmental consequences of individual and household behavior. See JASON J. CZARNEZKI, EVERYDAY ENVIRONMENTALISM: LAW, NATURE \& INDIVIDUAL BEHAVIOR 11 (2011) (noting that increased consumption of electronics and appliances has depleted natural resources and increased pollution); Hope M. Babcock, Assuming Personal Responsibility for Improving the Environment: Moving Toward a New Environmental Norm, 33 HARV. ENVTL. L. REV. 117 (2009) (discussing the aggregate environmental impact of individual activities and barriers to changing individual behavior); John C. Dernbach, Harnessing Individual Behavior to Address Climate Change: Options for Congress, 26 VA. ENVTL. L.J. 107, 108 (2008) (analyzing how Congress can engage individuals in implementing climate change legislation); Andrew Green, Self Control, Individual Choice, and Climate Change, 26 VA. ENVTL. L.J. 77, 78 (2008) (examining barriers to behavioral change, even for individuals who value environmental action); Douglas A. Kysar \& Michael P. Vandenbergh, Climate Change and Consumption, 38 ENVTL. L. REP. 10825, 10826 (2008) (noting focus of 1970 s environmental statutes on industrial emissions standards, not consumption); Michael P. Vandenbergh \& Anne C. Steinemann, The Carbon Neutral Individual, 82 N.Y.U. L. REV. 1673, 1676 (2007) (noting overwhelming focus of federal and state regulators on large industrial sources of emissions and exploring prospects for reducing carbon emissions from individuals and households). This scholarship is helpful both in spotlighting the environmental impact of individual behavior and in proposing policy solutions to lessen this impact, challenging conventional wisdom that consumer desire and individual consumption are beyond the realm of policy intervention.

16. Kysar \& Vandenbergh, supra note 15, at 10828.

17. See, e.g., REAL PROSPECTS REPORT; supra note 1, at 8 (estimating that it costs 2.7 cents/kwh to conserve electricity, whereas the retail price of residential electricity is 10.6 cents/kwh). 
in the initial purchase price of more efficient equipment. Numerous studies have found substantial net benefits from the programs, with relatively quick "payback periods" (in which consumers can recoup higher upfront costs within one to three years). ${ }^{18}$ Improving energy efficiency does not always result in higher retail prices for products. For some products-such as refrigerators and furnaces-real retail prices have declined significantly since the 1970 s at the same time that manufacturers have achieved dramatic improvements in energy efficiency. ${ }^{19}$

With the prospect of emissions reductions and cost savings, it is now widely recognized to the point of cliche that efficiency measures are the low-hanging fruit of climate change mitigation policy. Secretary of Energy Steven Chu extended this metaphor: "[E]nergy efficiency is not just low-hanging fruit; it is fruit that is lying on the ground. And energy efficiency means money back in your pocket because you pay less on your energy bills." 20

The second goal of product efficiency standards is to reduce energy consumption, with associated reductions in both greenhouse gas emissions and conventional pollution. The energy savings can be dramatic. In 2009, for example, the United States saved more energy from refrigerator efficiency standards alone than it produced from solar and wind power combined. ${ }^{21}$ The American Council for an Energy Efficient Economy ("ACEEE") has estimated that feasible efficiency standards could avoid almost 470 million metric tons of $\mathrm{CO}_{2}$ emissions annually in the United States by 2035, equivalent to the annual emissions from 118 coal-fired power plants. ${ }^{22}$ Looking globally,

18. See, e.g., ELLIS, supra note 3, at 12-15 (setting forth a summary of efficiency and price trends for equipment and appliances); INT'L ENERGY AGENCY, WORLD ENERGY OUTLOOK 2007: CHINA AND INDIA INSIGHTS 387 (2007), available at http:/www.iea.org/textbase/nppdf /free/2007/weo_2007.pdf (noting a three-and-a-half year payback period for Chinese efficiency standards for refrigerators, given then-prevailing electricity prices in China).

19. See ELLIS, supra note 3, at 62 (surveying MEPS in Europe, the United Kingdom, the United States, and Australia and concluding that the programs resulted in energy efficiency increases between $10 \%$ to $60 \%$ in covered products, along with declines in real prices between $10 \%$ and $45 \%$ ).

20. Steven Chu, Cleaning Up: Energy and Climate Bill Will Boost the Economy, RICHMOND TIMES-DisPATCH, July 22, 2009, http://www2.timesdispatch.com/news/2009/jul/22/edchu22_20090721-173805-ar-36524/.

21. See David Biello, U.S. Unveils a \$350-Million Energy-Efficiency Initiative at Copenhagen, SCI. AM., Dec. 15, 2009, http://www.scientificamerican.com/article.cfm?id=solarlanterns-light-chu.

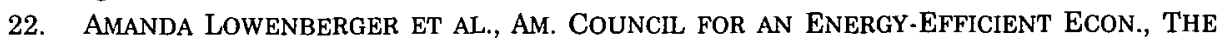
EFFICIENCY BOOM: CASHING IN ON THE SAVINGS FROM APPLIANCE STANDARDS iv (2012), available at http://www.acee.org/sites/default/files/publications/researchreports/a123.pdf. 
McKinsey \& Co. has estimated that a major governmental push for energy efficiency could reduce 2020 energy consumption by 9.1 quadrillion BTUs, or roughly $23 \%$ of projected global demand, potentially abating up to 1.1 gigatons of greenhouse gases annually. ${ }^{23}$

The third goal of product efficiency standards is to improve energy planning and free up investor capital that would otherwise flow to power plant construction and other energy supply projects. ${ }^{24}$ The ability to ensure electric grid stability through reduced demand, rather than increased supply, is a major consideration that supports expansion of MEPS. Given fierce public opposition to new coal and nuclear power plants and to new transmission lines, ${ }^{25}$ the decentralized approach of demand reduction is an attractive option for policymakers.

Improving the efficiency of energy end uses is a critical component of demand reduction. In a stunning finding that was largely overlooked in the media, the National Academy of Sciences recently concluded that implementing realistic efficiency measures for existing and new buildings could obviate the need to build any new power plants in the United States. ${ }^{26}$ Moreover, as energy expert Amory Lovins has explained, a kilowatt saved "downstream" at the electrical outlet saves up to ten kilowatts "upstream" at the generating station, because of unavoidable energy loss in electricity

23. Hannah Choi Granade et al., Energy Efficiency: Unlacking the US Opportunity, in ENERgy Efficiency: A Compelling Global Resource 4, 4 (McKinsey \& Co. ed., 2010), available at http:/www.mckinsey.com/Search.aspx?q=a\%20compelling\%20global\%20resource; see also REAL PROSPECTS REPORT, supra note 1, at 4 (deploying available technology to improve efficiency could result in U.S. energy consumption that is $17-20 \%$ lower than business-as-usual projections in 2020 and $25.31 \%$ lower in 2030 ).

24. Product efficiency standards are particularly important for avoiding construction of expensive "peaking units" that supply power during periods of peak demand. Supplying peak power is vastly more expensive for utilities than supplying off-peak power, see David. B. Spence, Can Law Manage Competitive Energy Markets?, 93 CoRNELL L. REv. 765, $796-97$ (2008), so improving the efficiency of appliances that tend to run at peak periods (such as air conditioning) helps to stabilize electricity prices.

25. Stephen Ansolabehere \& David M. Konisky, Public Attitudes Toward Construction of New Power Plants, 73 PUB. OPINION Q. 566 (2009) (finding that a substantial majority of Americans oppose siting new coal, nuclear, or natural gas generating plants in their area).

26. See REAL PROSPECTS REPORT, supra note 1, at 5 (concluding that feasible efficiency improvements in the building sector, including efficiency upgrades in electrical equipment, would mean that the United States would not need new generating capacity, except to address regional supply imbalances, replace obsolete generation assets, or substitute more environmentally benign generation sources). While efficiency improvements in the building sector include items such as better insulation, which are typically not covered by MEPS, most of the efficiency improvements discussed in the NAS report come from improvements in energy. using products. Space heating, cooling, and ventilation are the largest consumers of energy in buildings, followed by lighting. Id. at 6 . 
production and transmission. ${ }^{27}$ Therefore, making products more efficient provides a crucial leverage point both for reducing power plant emissions and for avoiding new power plant construction.

In environmental law parlance, MEPS are performance standards (setting minimum efficiency standards for a product class), rather than design standards (dictating the particular technology that must be deployed to reach that objective). ${ }^{28}$ This is a critical distinction. Performance standards allow for design flexibility and promote manufacturer innovation to meet the target, without locking in any particular technological approach. As Michael Porter and other scholars of industrial policy have noted, performance standards focus on outcomes-rather than particular technologies-and can promote creative diversity within industry. ${ }^{29}$

While performance standards promote private-sector flexibility, substantial government oversight is required to design and implement them. In the regulatory process for MEPS, a government agency must gather economic and technical information, consult with stakeholders, and set the performance standard for each product class. Postpromulgation, a government agency must monitor compliance and enforce against violators. MEPS rely on the coercive power of the state to shape what products can be sold. To borrow a phrase from Lawrence Lessig, MEPS regulate through "architecture"- they change the physical "features of the world" within which market actors make their choices. ${ }^{30}$

One important limitation of product standards is that they cannot guarantee absolute reductions in energy demand. For several reasons, total national energy consumption may increase even after MEPS are in place. Consumers, as they become wealthier over time,

27. See AMORY B. Lovins, ROCKY MOUNTAIN INST., ENERGY END-USE EFFICIENCY 5 (2005), available at http://www.rmi.org/Knowledge-Center/Library/E05-16_EnergyEndUseEfficiency.

28. See Adam B. Jaffe, Richard G. Newell \& Robert N. Stavins, A Tale of Two Market Failures: Technology and Environmental Policy, 54 ECOLOGICAL ECON. 164, 171 (2004) (advocating that technology policy should be "technology neutral, encouraging all efforts that achieve specified objectives without focusing on a particular approach").

29. See, e.g., Michael E. Porter \& Claas Van der Linde, Green and Competitive: Ending the Stalemate, HARV. BuS. REV., Sept.-Oct. 1995, at 120, 124; see also RoBERT V. PERCIVAL ET AL., EnViRonmental REgUlation: LaW, Science, AND POLICY 153 (6th ed. 2009) (“Technological innovation that expands the menu, increases the capability, or reduces the cost of available pollution control technology is commonly viewed as a desirable goal."); Cary Coglianese et al., Performance-Based Regulation: Prospects and Limitations in Health, Safety, and Environmental Protection, 55 ADMIN. L. REV. 705, 711 (2003) ("Performance standards can also accommodate technological change and the emergence of new hazards in ways that prescriptive technologybased standards generally cannot.").

30. Lawrence Lessig, The New Chicago School, 27 J. LEGAL STUD. 661, 663 (1998). 
may simply choose to buy more energy-using products or to operate them longer (as occurred with air conditioning in the United States). ${ }^{31}$ Population growth may swamp the gains in efficiency from regulation. And efficiency standards are subject to the so-called "rebound effect," in which consumers may use products more intensively as products become more energy efficient, even holding wealth constant. ${ }^{32}$

Many commentators have pointed to these wealth effects, population growth effects, and rebound effects as reasons why an energy efficiency strategy for climate change is futile or even counterproductive. ${ }^{33}$ Media outlets have amplified these arguments,

31. In a widely noted 2010 article in The New Yorker, David Owen alleged that efficiency regulation was futile, noting that between 1993 and 2005, U.S. air conditioners increased their efficiency by $28 \%$, yet homes used $37 \%$ more energy for air conditioning during this same period. David Owen, The Efficiency Dilemma, THE NEW YORKER, Dec. 20, 2010, at 80-81. These figures hardly illustrate that efficiency regulation was ineffective, however. The increase in energy usage was mainly attributable to a wealth effect in which Americans moved to larger homes and shifted to central air conditioning rather than room air conditioning. See U.S. CENSUS BUREAU,

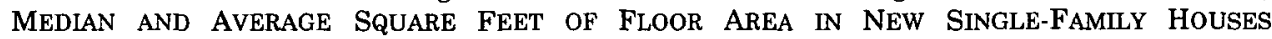
COMPLETED BY LOCATION (2010), available at http://www.census.gov/const/ C25Ann /sftotalmedavgsqft.pdf (median house size increased from 1,945 square feet in 1993 to 2,227 square feet in 2005); FREDERICK J. EGGERS \& ALEXANDER THACKERAY, U.S. DEP'T OF HOUS. \& URBan Dev. OfFICE of Policy Dev. \& ReSEARCh, 32 Years of Housing Data 17 fig.11 (2007), available at http://www.huduser.org/ datasets/ahs/AHS_taskC.pdf (share of all U.S. homes with central air grew from around $45 \%$ in 1995 to $65 \%$ in 2005). Owen fallaciously attributed the rapid rise in energy consumption from air conditioning to a "rebound" from efficiency regulation, rather than to these exogenous wealth effects, which are beyond the control of environmental regulators. Given the wealth-driven demand for more air conditioning, MEPS were successful in that the air conditioners consumers actually purchased were substantially more efficient due to government policy.

32. Global View Sustainability Servs. ET al., European Comm'N, AdDREssing the REBOUND EFFECT 6 (2011), available at http://ec.europa.eu/environment/eussd/pdf /rebound_effect_report.pdf.

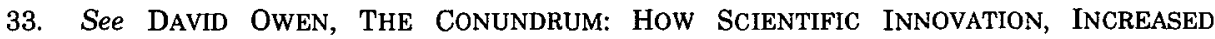
EfFiciency, and Good InTENTIONS CAN MAKe OUR ENERgy and Climate Problems Worse 101-02 (2012) (noting that during the period in which new refrigerators increased in efficiency and decreased in price, total energy consumption for refrigeration climbed); Lorna A. Greening, David L. Green \& Carmen Difiglio, Energy Efficiency and Consumption - The Rebound Effect - A Survey, 28 ENERGY POL'Y 389, 389-92 (2000) (positing that improvements in efficiency will reduce the per-unit price of energy services and cause energy consumption to increase); David A. Farenthold, Are American Homes More Energy Efficient? Not Exactly., WASH. PosT, Sept. 30, 2010, http://www.washingtonpost.com/wp-dyn/content/article/2010/09/29/AR2010092906585.html (noting that energy use in the average American home has remained stable since 1970 because although appliances and heating have become vastly more efficient, home sizes have increased and Americans use more electronic gadgets); Owen, supra note 31, at 78 (noting that population increase has caused a rapid increase in appliance purchases); John Tierney, When Energy Efficiency Sullies the Environment, N.Y. TIMES, Mar. 8, 2011, at D1 (arguing that efficiency measures may be ineffective if the immediate goal is reducing greenhouse gas emissions). 
caricaturing energy efficiency policy as self-defeating. ${ }^{34}$ But empirical studies have found that the "rebound effect" is modest (anywhere from $10 \%$ to $30 \%$, depending on the product or industry). ${ }^{35}$ In other words, the rebound effect cuts into, but does not negate, the benefits of promoting efficiency as climate policy. Moreover, none of these effects undermine the project of regulating for energy efficiency once it is acknowledged that the goal of product standards is not to lower global energy consumption in absolute terms: it is to reduce energy demand compared to the business-as-usual pathway where energy demand is rising rapidly. Advocates of MEPS do not suggest that MEPS alone will lead to a reduction in global energy consumption from today's levels. They are but one crucial "wedge" in the larger climate puzzle. ${ }^{36}$

\section{B. Standards in Practice: The United States and the European Union}

The United States and the EU have both embraced product regulation as a climate change strategy and have substantially expanded their product standards programs in the past five years. In this Section, I compare the approaches of these two jurisdictions to illustrate the regulatory and political challenges of relying on product standards as climate change policy.

\section{Efficiency Regulation in the United States}

The U.S. approach to product efficiency regulation has been characterized by close cooperation with industry stakeholders, consensus-oriented standards, and incremental improvements (rather than radical leaps) in product efficiency. Most of the U.S. MEPS-for products such as refrigerators, heating and cooling equipment, and lighting-have been established by statute, rather than by delegation

34. See Owen, supra note 31 , at 78 (arguing that increased consumption may negate the effects of energy efficiency measures); Tierney, supra note 33, at D1 (arguing that the benefits of energy efficiency measures have been overstated).

35. STEve SORRELL, UK ENERGY RESEARCH CTR., THE REBOUND EFFECT: AN ASSESSMENT OF THE EVIDENCE FOR ECONOMY-WIDE ENERGY SAVINGS FROM IMPROVED ENERGY EFFICIENCY vii-viii (2007), available at http://www.ukerc.ac.uk/Downloads/PDF/07/0710ReboundEffect/ 0710ReboundEffectReport.pdf; see also GLOBAL VIEW SUSTAINABILITY SERVS. ET AL., supra note 32 , at 9 (detailing measurement methodology for rebound effects).

36. See Stephen Pacala \& Robert Socolow, Stabilization Wedges: Solving the Climate Problem for the Next 50 Years with Current Technologies, 305 SCIENCE 968 (2004); see also GLOBAL VIEW SUSTAINABILITY SERVS. ET AL., supra note 32, at 16-17 (advocating a "mixed instrument" approach in which technology-based efficiency measures are coupled with energypricing changes, provision of better information to consumers, environmental taxes, and other measures). 
from Congress to the Department of Energy ("DOE"). ${ }^{37}$ The standards set forth by statute are typically based on negotiated consensus agreements between product manufacturers and environmental advocates. ${ }^{38}$ In other words, Congress has been willing, on a bipartisan basis, to enact detailed performance standards for products because the standards codified agreements already reached by the manufacturers themselves. Congress has then delegated the detailed rulemaking and implementation to DOE, and has also charged DOE with updating standards over time. ${ }^{39}$

Until recently, the rulemaking process at DOE was sluggish. 40 In the 1990s and 2000s, DOE fell significantly behind its statutorily mandated rulemaking schedules, ${ }^{41}$ and by 2005 , DOE had still not

37. The following federal statutes contain energy efficiency standards for products: Energy Policy and Conservation Act (EPCA), Pub. L. No. 94-163, 89 Stat. 871, amended by National Energy Conservation Policy Act, Pub. L. No. 95-619, 92 Stat. 3206 (codified as amended in scattered sections of 42 U.S.C.); National Appliance Energy Conservation Act (NAECA) of 1987, 42 U.S.C. $\$ \S$ 6291-6309 (2006), amended by National Appliance Energy Conservation Amendments of 1988, Pub. L. No. 100-357, 102 Stat. 671, 42 U.S.C. $§ \S 6291-6309$ (2006); Energy Policy Act of 1992, Pub. L. No. 102-486, 106 Stat. 2776 (codified as amended in scattered sections of 16, 25, 26, 30, and 32 U.S.C.); Energy Policy Act of 2005, Pub. L. No. 109-58, 119 Stat. 594 (codified as amended in scattered sections of 16, 22, 26, and 42 U.S.C.); Energy Independence and Security Act of 2007, Pub L. No. 110-140,121 Stat. 1492 (codified in scattered sections of 2, 15,42 , and 46 U.S.C.). DOE's current appliance efficiency regulations are contained at 10 C.F.R. $\S 430$ et seq. (2012) (standards for consumer products) and 10 C.F.R. $\$ 431$ et seq. (2012) (standards for commercial and industrial equipment).

38. See LOWENBERGER ET AL., supra note 22, at 63 (detailing the history of energy efficiency standards in the United States).

39. See, e.g., NAECA $\S 325(\mathrm{~b})-(\mathrm{h})$ (requiring DOE to amend standards within three to ten years, depending on the product).

40. See Steven Nadel, Appliance and Equipment Efficiency Standards, 27 ANN. REV. ENERGY \& ENV'T 159, 182 (2002) (noting that the DOE rulemaking process can be "contentious and long" and that rulemakings designed to last three years have often taken ten years). The rulemaking process calls for analyzing the technical and economic issues associated with setting an energy efficiency standard for a product category, proceeding through notice and comment rulemaking, and then issuing the final rule. Experts at the Lawrence Berkeley National Laboratory and other contractors advise DOE on the technical and economic aspects of each rule. See U.S. GOV'T ACCOUNTABILITY OFFICE, GAO-07-42, ENERGY EFFICIENCY: LONG-STANDING PRoBlems WITH DOE'S PRogram For SETTING EFFICIENCY STANDARDS CONTINUE TO RESULT IN FORGONE ENERGY SAVINGS 2 (2007), available at http://www.gao.gov/products/GAO-07-42. The rules are also reviewed by the White House Office of Information and Regulatory Affairs. About OIRA, WHITEHOUSE.GOV, http://www.whitehouse.gov/omb/inforeg_administrator (last visited Sept. 2, 2012).

41. See U.S. Gov'T ACCOUNTABILITY OFFICE, supra note 40, at 5 (noting that DOE had missed all thirty-four of the rulemaking deadlines that had been established for twenty different consumer product and industrial equipment categories). 
completed rulemakings that Congress had mandated in two statutes from the late 1980s. 42

Under the Obama Administration, however, the program has expanded considerably, and DOE has promulgated product standards at an unprecedented rate. Between January 2009 and March 2012, DOE completed new or updated MEPS for seventeen product classessuch as water heaters, refrigerators, and fluorescent lighting-and eleven more standards are expected to be issued by January $2013 .{ }^{43}$

By volume of rulemaking, this is easily the biggest environmental regulatory effort in the entire Obama Administration. Indeed, expanding direct government regulation of energy efficiency is one of President Obama's principal environmental legacies. In addition to issuing a torrent of new efficiency standards for appliances and electronics that had been stalled in the Bush Administration, the Obama Administration also substantially increased automobile fuel efficiency standards ${ }^{44}$ and promoted energy efficiency standards for buildings in the American Recovery Act. ${ }^{45}$ DOE has promulgated more MEPS since January 2009 than it issued in all prior years since the founding of the agency in $1978 .{ }^{46}$

The U.S. regulatory approach aims for incremental improvements in energy efficiency by setting standards that reflect (but do not exceed) the most efficient existing products on the market. As a result, regulation has had the intended effects of saving energy

42. Under the Energy Policy and Conservation Act of 1992, DOE was obligated to set energy efficiency standards for categories of consumer products and industrial equipment including: clothes washers; refrigerators, refrigerator-freezers, and freezers; small furnaces; central air conditioners and heat pumps; clothes dryers; dishwashers; fluorescent lamp ballasts; room air conditioners; water heaters; direct heating equipment; furnaces; general service fluorescent lamps and incandescent lamps; kitchen ranges and ovens; mobile home furnaces; pool heaters; electric motors; and distribution transformers. Id. at 1-8. By 2009, the only consumer products for which rulemaking had been completed were refrigerators, refrigerator-freezers, freezers, small furnaces, and clothes washers. Id. at 5. In that year, the agency was sued over its lassitude, resulting in a consent decree imposing tighter deadlines. Consent Decree at 9-11, State v. Bodman, No. 05 Civ. 7807 (S.D.N.Y. Nov. 6, 2006).

43. LOWENBERGER ET AL., supra note 22, at iv.

44. See Nick Bunkley, New Gas Economy Rules Generate Wide Support, N.Y. TIMES, Jan. 17, 2012, http://www.nytimes.com/2012/01/18/business/energy-environment/new-fuel-economyrules-win-broad-support.html (discussing the Obama Administration's proposed standards that would require automakers to increase the average, unadjusted fuel-economy of their vehicles to 54.5 miles per gallon).

45. American Recovery and Reinvestment Act of 2009, H.R. 1, 111th Cong. $\$ 410$ (2009) (providing incentives to states to enact building energy efficiency codes).

46. LOWENBERGER ET AL., supra note 22, at 5, 16. 
and knocking the worst-performing products off the market, but the regulations themselves have rarely been technology forcing. ${ }^{47}$

There are three main reasons why the United States does not rely on technology-forcing regulation here. First, as noted above, MEPS set by Congress have been based on consensus negotiations involving multiple industry players who would oppose mandates that they could not meet with available technology. ${ }^{48}$ Second, by statute, DOE must establish MEPS at a level that achieves "the maximum improvement in energy efficiency" that DOE determines is "technologically feasible and economically justified." 49 Finally, very stringent efficiency standards, if promulgated by DOE, would be difficult to justify under cost-benefit tests applied in the Obama Administration. This is because the Administration established a relatively low dollar figure (\$21 per ton) for the benefits of avoiding $\mathrm{CO}_{2}$ emissions, ${ }^{50}$ and that figure, although heavily criticized, has been used in the regulatory reviews for efficiency standards since 2010.

Despite the incremental, consensus-oriented nature of the program, the U.S. regulatory approach to energy efficiency has yielded substantial energy savings and environmental benefits. The ACEEE has estimated that if efficiency standards enacted before 2008 had never been enacted, U.S. electricity use would have been $7 \%$ higher in

47. Technology-forcing regulation refers to regulation that commands results beyond the capabilities of existing technology. See John Copeland Nagle, Pornography As Pollution, 70 MD. L. REV. 939, 970 (2011) ("Technology-forcing laws require pollution reductions that cannot be achieved with existing technologies, thereby requiring technological innovation."); Cass R. Sunstein, Cost-Benefit Default Principles, 99 MICH. L. REv. 1651, 1679 (2001) (defining a technology-forcing regulation as one that "require[s] companies to innovate, and thus to do more than what current technology permits").

48. See U.S. GOV'T ACCOUNTABILITY OFFICE, supra note 41, at 2.

49. 42 U.S.C. $\$ 6295(0)(2)(A)$ (2006). An economically justified standard is one where the benefits exceed costs, taking into account seven factors such as the economic impact on manufacturers and consumers, operating cost savings over time, any lessening of the performance of the products, and impacts on competitiveness. Id. $\S 6295(\mathrm{o})(2)(\mathrm{B})(\mathrm{I})-(\mathrm{VII})$.

50. The $\$ 21$ per ton figure was developed by an interagency working group in 2010 . INTERAGENCY WORKING GRP. ON SOC. COSTS OF CARBON, SOCIAL COST OF CARBON FOR REGULATORY IMPACT ANALYSIS - UNDER EXECUTIVE ORDER 12866, at 3 (2010). The economic models on which this figure is based have been heavily criticized, however. See Elizabeth A. Stanton, The Social Cost of Carbon, ENVTL. F., Nov./Dec. 2011, at 38, 39 (noting that the economic models used to calculate the social cost of carbon are highly sensitive to assumptions about climate sensitivity and the relationship between temperature increases and economic damages). Numerous studies have estimated the social cost of carbon at many times that figure. See id, at 39-41 (noting that using a lower discount rate greatly increases the social cost of $\mathrm{CO}_{2}$ emissions and discussing studies with estimates as high as $\$ 1,550$ per ton in the year 2050); see also RUTH GREENSPAN BELL \& DIANNE CALLAN, ENVTL. LAW INST., MORE THAN MEETS THE EYE: THE Social Cost OF CARBon IN U.S. Climate Policy, IN PLAIN ENGlish 3-4 (2011) (discussing studies that estimate the social cost of $\mathrm{CO}_{2}$ emissions at $\$ 41-\$ 124$ per ton). 
2010.51 Additionally, the ACEEE has estimated that pre-2008 standards (not including the major standards enacted under the Obama Administration) will cut U.S. $\mathrm{CO}_{2}$ emissions by $6.5 \%$ by 2020 and $7.5 \%$ by 2030 , compared to a business-as-usual baseline. ${ }^{52}$ According to the ACEEE, net savings to consumers and businesses from the standards already adopted will total $\$ 1.1$ trillion by $2035 .{ }^{53}$ Other studies have come to similar conclusions about the environmental benefits and cost effectiveness of these regulations. ${ }^{54}$

\section{Efficiency Regulation in the European Union}

The MEPS program in the EU differs in two principal respects from the program in the United States. First, EU legislation is more comprehensive than its U.S. counterpart, as it provides authority to set standards for any product class that uses an external energy source-potentially thousands of different product classes. ${ }^{55}$ Second, in the EU, product standards are a core plank of a much larger EU-wide strategy to improve energy efficiency by $20 \%$ and reduce greenhouse gas emissions to $20 \%$ below 1990 levels by 2020.56 The United States

51. MaX Neubauer et AL., AM. COUNCIL FOR AN ENERGY-EFFicient ECON., Ka-BOOM!: THE POWER OF APPLIANCE STANDARDS iii (2009), available at http://www.aceee.org/sites /default/files/publications/researchreports/a091.pdf.

52. Id. at 11 .

53. LOWENBERGER ET AL., supra note 22, at $\mathrm{i}$. The average benefit-cost ratio for the twentysix evaluated standards is $4: 1$. That is, the product lifetime savings are, on average, four times larger than the upfront incremental costs for efficiency improvements. Id. at 8.

54. For example, a 2003 study concluded that the efficiency standards that took effect in the United States from 1988-2003 will capture cumulative reductions in energy use from 19882050 of $8 \%-9 \%$ relative to a no-standards baseline. The corresponding cumulative cost of these standards was estimated at $\$ 200-\$ 250$ million (2002 dollars), with a cumulative (through 2050) benefit/cost ratio of 2.75:1. ELIZABETH DORIS, JAQUELIN COCHRAN \& MARTIN VORUM, NAT'L RENEWABLE ENERGY LAB., ENERGY EFFICIENCY POLICY IN THE UNITEd STATES: OverVIEW OF TRENDS AT DIFFERENT LEVELS OF GOVERNMENT 13 (2009), available at http://www.nrel.gov /docs/fy 10 osti/46532.pdf. Another study estimated $4 \%$ and $8 \%$ energy use reductions resulting from standards in the commercial and residential sectors, respectively, for standards in place from 1987-2006. Id.

55. The Eco-Design Directive applies to a sweeping range of products. Products subject to the Directive include "any good that has an impact on energy consumption during use which is placed on the market and/or put into service, and includes parts intended to be incorporated into energy-related products . . . ." Directive 2009/125/EC of the European Parliament and of the Council of 21 October 2009 Establishing a Framework for the Setting of Ecodesign Requirements for Energy-Related Products, 2009 O.J. (L 285) 10, 15. The Directive applies only to products sold in volumes greater than 200,000 units per year. See id. at 20.

56. The strategy is laid out in a comprehensive 2006 "Action Plan" for Energy Efficiency. Action Plan for Energy Efficiency: Realising the Potential, COM (2006) 545 final (Oct. 19, 2006), available at http://ec.europa.eu/energy/action_plan_energy_efficiency/doc/com_2006_0545_en.pdf. 
has no comparable national targets, nor an equivalent national strategy to reduce energy consumption or emissions. ${ }^{57}$ On a per capita basis, energy consumption in the United States is twice as high as in Europe. 58

The legal basis for EU product efficiency regulation is the 2005 Eco-Design Directive, a framework directive that provides authority to the European Commission to set MEPS for a wide variety of product classes (excluding automobiles, which are covered by other legislation). ${ }^{59}$ Under this Directive, the Commission is empowered to set performance standards not only for products that use energy, such as motors, lighting, and refrigerators, but also for other products that affect energy consumption, such as insulation, windows, and showerheads. The Commission estimates that MEPS promulgated under the Eco-Design Directive could reduce European electricity consumption by more than $12 \%$ from 2009 levels by $2020^{60}$-a remarkable energy savings from a single piece of legislation.

The Eco-Design Directive symbolizes a major reorientation of European environmental policy. The EU is shifting from addressing solely the environmental impacts of manufacturing processes toward addressing, more holistically, the life-cycle environmental impacts of products themselves. ${ }^{61}$ This shift is exemplified by the Integrated

57. President Obama committed at the Copenhagen Climate Summit to reduce U.S. greenhouse gas emissions by $17 \%$ below 2005 levels (or approximately to 1990 levels) by 2020 . Lisa Friedman, U.S. Bound by Obama's Copenhagen Emissions Pledge-U.N. Official, N.Y. TIMES, Jan. 20, 2010, http://www.nytimes.com/gwire/2010/01/20/20greenwire-us-bound-byobamas-copenhagen-emissions-pledge-17687.html. However, this Executive Branch commitment was not supported by Congress and has not been codified by statute.

58. See Noah M. Sachs, Greening Demand: Energy Consumption and U.S. Climate Policy, 19 DUKE ENVTL. L. \& POL'Y F. 295, 300 (2009) (comparing per capita energy consumption of the United States with that of several European countries). U.S. energy intensity (energy consumed per dollar of GDP) is about one-third higher in the United States compared to other developed countries. See REAL PROSPECTS REPORT, supra note 1, at 26-27. While differences in industry composition and climate account for some of this disparity, about fifty percent of the observed differences in the energy intensity of developed economies result from differences in energy efficiency. $I d$.

59. The Eco-Design Directive provides authority to regulate the energy use of products as well as toxicity, manufacturing impacts, disposal impacts, and other negative environmental consequences from products. Eco-Design Directive, supra note 55, at art. 15. The emphasis of the Commission to date has been on energy consumption, however.

60. EUROPEAN COMM'N, ECODESIGN YOUR FUTURE 4, available at http://ec.europa. eu/enterprise/policies/sustainable-business/ecodesign/files/brochure_ecodesign_en.pdf.

61. See Integrated Product Policy: Building on Environmental Life-Cycle Thinking, at 4-5, COM (2003) 302 final (June 18, 2003), available at http://eur-lex.europa.eu/LexUriServ LexUriServ.do?uri=COM:2003:0302:FIN:en:PDF (discussing EU strategy for reducing environmental footprint of products). 
Product Policy ("IPP"), of which the Eco-Design Directive is one component. The IPP was adopted in 2003 to establish "a new growth paradigm and a higher quality of life through wealth creation and competitiveness on the basis of greener products."62

While the Eco-Design Directive lays out a broad framework for addressing the climate impacts of products, the actual targets and timetables for achieving efficiency improvements are contained in "implementing measures" that the European Commission began to enact in 2008.63 As of June 2012, the Commission has passed implementing measures for thirteen different product categories. ${ }^{64}$ For each product category, the energy performance standard is set through a process of negotiation with key stakeholders ${ }^{65}$ and through consideration of technical, economic, and environmental factors. ${ }^{66}$

As an example of how this process works, consider the implementing measure for televisions and monitors. The Commission found that televisions and monitors in the EU consumed fifty-four terawatt-hours ("TWh") of electricity in 2005, and it projected that electricity consumption for televisions and monitors would reach 132 TWh by 2020 (an amount equal to the entire projected electricity consumption of Sweden in that year). ${ }^{67}$ Concluding that there were available, low-cost technologies that could improve efficiency, the Commission ultimately set the minimum energy performance standard at a level that called for $20 \%$ to $30 \%$ less energy usage than the 2009 average for those products. ${ }^{68}$ It projects that the new standard will avoid thirty-four million tons of $\mathrm{CO}_{2}$ emissions over ten years. ${ }^{69}$

62. Green Paper on Integrated Product Policy, at 3, COM (2001) 68 final (Feb. 7, 2001), available at http://eur-lex.europa.eu/LexUriServ/site/en/com/2001/com2001_0068en01.pdf.

63. Bernhard Kuschnik, The European Union's Energy Using Products-EuP-Directive 2005/32 EC: Taking Transnational Eco-Product Design Regulation One Step Further, 27 TEMP. J. SCI. TECH. \& ENVTL. L. 1, 5-6 (2008).

64. The full set of regulations, including the energy performance standards issued for each product, can be found at http://ec.europa.eu/enterprise/policies/sustainable-business/documents /eco-design/legislation/implementing-measures/index_en.htm.

65. Id.

66. Id.

67. Commission Staff Working Document, Accompanying Document to the Commission Regulation Implementing Directive 2005/32/EC with Regard to Ecodesign Requirements for Televisions: Full Impact Assessment, at 4, SEC (2009) 1011 final (July 22, 2009), available at http://ec.europa.eu/energy/efficiency/ecodesign/doc/legislation/sec_2009_1011.pdf.

68. Id. at 6-7.

69. Id. 
The EU has set efficiency targets that are more ambitious than the current averages for each product class. But they do not necessarily reflect the highest level of efficiency achievable, or the best performer in a product class. Still, as in the United States, the targets have the effect of phasing out the least efficient products on the market.

The scope for future rulemaking is wider in Europe than in the United States. Because the Eco-Design Directive empowers the Commission to enact implementing regulations for most energy-using devices on the market, the Commission has wide-ranging authority to expand the use of MEPS in Europe. In contrast, in the United States, Congress must specifically authorize MEPS for each new product category (with some residual authority for DOE to amend standards on its own)..$^{70}$

This difference in authority provides important flexibility for the EU to set standards for the next wave of electronic products, those not yet covered by efficiency standards. Today's homes are a hive of electronic devices - with dozens of items plugged in at any one time, including cable boxes, video game consoles, electronic picture frames, home networking equipment, and multiple cell phone chargers. ${ }^{71}$ According to a study by the Natural Resources Defense Council, a U.S. family with a digital video recorder and a cable set-top box uses more energy to power those devices than to power its refrigerator. ${ }^{72}$ The study also estimated that cable set-top boxes in the United States use as much electricity annually as all households in Maryland. ${ }^{73}$ Given these trends, policymakers need to look beyond traditional appliances in pursuing an energy efficiency strategy, and one challenge of a regulatory approach is the need to update standards frequently to respond to market conditions, consumer preferences, and technological changes. The EU, with broad authority over energy-using products, is well positioned to respond to these changes.

70. See, e.g., 42 U.S.C.A. $\$ 6295(\mathrm{~m})$ (West 2012).

71. The average California home, for example, now contains more than forty products that are continuously drawing power greater than 110 watts. REAL PROSPECTS REPORT, supra note 1 , at 86 .

72. Natural Res. Def. CouncIL, BetTer Viewing, Lower ENergy Bills, and Less POLLUTION: IMPROVING THE EFFICIENCY OF TELEVISION SET-TOP BOXES 2 (2011), available at http://www.nrdc.org/energy/files/settopboxes.pdf.

73. Id. at 1 . 


\section{Comparing Product Regulation to Alternative Climate POLICIES}

As the United States, the EU, and other jurisdictions adopt product standards to reduce greenhouse gas emissions, there are two important questions that need to be addressed. First, could the efficiency of energy-using products be promoted even more effectively through other, nonregulatory tools, such as product labeling or carbon pricing aimed at raising the price of energy? And second, if a regulatory approach to product standards is to be expanded, how should MEPS be structured to avoid some traditional drawbacks of command-and-control regulation, such as policy rigidity or adverse impacts on private-sector innovation? In this Part, I compare MEPS to alternative instruments for promoting energy efficiency and respond to some potential criticisms of a regulatory approach.

\section{A. Energy Market Failures and Barriers}

Government intervention to address escalating energy consumption is justifiable because energy markets are prone to market failure, resulting in persistent suboptimal investment in climate-friendly technology. The most significant market failure is that the environmental consequences of energy consumption, including global climate change and conventional air pollution, are unpriced. Energy consumers-from individuals to multinational firms - are externalizing the costs associated with climate and public health damage. Since they are not paying the social cost of every unit of energy they consume, they have suboptimal incentives to conserve.

Economists have identified additional failures in energy markets as well. These have been exhaustively documented elsewhere, ${ }^{74}$ and I provide just a brief overview here. One notable market failure is that the interests of those who purchase energyusing appliances (such as landlords) often diverge from the interests of those who pay the energy costs (such as tenants). Under these split-

74. See, e.g., REAL PROSPECTS REPORT, supra note 1, at 96-104 (discussing market failures and barriers to energy efficiency); Adam B. Jaffe, Richard G. Newell \& Robert N. Stavins, Economics of Energy Efficiency, in 2 ENCYCLOPEDIA OF ENERGY 79, 83-85 (Cutler J. Cleveland ed., 2004) (distinguishing between market failures that immediately impact the adoption of energy-saving technology and those that do not); Jaffe et al., supra note 28, at 166-68 (analyzing the interaction between market failures associated with environmental externalities and market failures associated with technological innovation); Sachs, supra note 58, at 305-11 (discussing principal-agent divergence, information and search costs, high discount rates, and utility incentives). 
incentive conditions, energy is consumed by end users who have little control over the efficiency of the products they use. Conversely, energy is also consumed by people (such as hotel guests and office workers) who are shielded, to some extent, from the costs of their consumption. ${ }^{75}$ Workers who routinely leave their computers on at work are reacting to the zero-price signal that prevails for energy use at the office.

Additionally, energy markets are plagued by information gaps and information asymmetry. There is a lack of comparative efficiency information for many products, ${ }^{76}$ and consumers often have little understanding of both their own energy usage and the current price of electricity, natural gas, or other fuels. ${ }^{77}$

In addition to these well-known market failures, several market barriers also create suboptimal energy efficiency investment. While not true market failures, ${ }^{78}$ these barriers tend to limit consumer adoption of energy efficient technologies. For example, capital constraints may preclude consumers and firms from making costeffective upfront investments in efficiency. Companies may simply overlook potential bottom-line savings from energy efficiency improvements, as many corporate managers do not consider energy efficiency to be a core activity of their firms, ${ }^{79}$ and there are few career rewards or bonuses for finding the savings. Purchasers of energyusing products have high discount rates for future energy savings, ${ }^{80}$ so

75. See Sachs, supra note 58, at 307-08 (discussing principal-agent divergence).

76. See id. at 298, 308-09, 314-16, for a discussion of limited consumer information on energy pricing and energy efficiency. See also REAL PROSPECTS REPORT, supra note 1, at 32 ("[S]ubstantial investments in time and effort may be required to find and study information about the potential energy-saving technologies, measures, and actions."); David Popp, Richard G. Newell \& Adam B. Jaffe, Energy, the Environment, and Technological Change 31-33 (Nat'l Bureau of Econ. Research, Working Paper No. 14832, 2009), available at http://www.nber.org/ papers/w14832.pdf (examining market failures caused by imperfect information).

77. See MCKINSEY \& Co., REDUCING U.S. GREENhouSE GAS EMISSIONS: How MUCH aT WHAT COST? 37 (2007) (examining abatement options for greenhouse gases, including providing better information to consumers about energy use); Sachs, supra note 58, at 308-09 (discussing high costs of consumers obtaining information on electricity pricing and usage).

78. REAL PROSPECTS REPORT, supra note 1, at 96-104 (discussing differences between true market failures, such as unpriced externalities, and market barriers, such as limited access to capital for upfront investments).

79. See Michael Vandenbergh et al., Implementing the Behavioral Wedge: Designing and Adopting Effective Carbon Emissions Reduction Programs, 40 ENVTL. L. REP. 10547, 10554 (2010) (citing a survey in which managers of one firm required a payback on energy efficiency investments of over $30 \%$ per year, a rate significantly higher than that of other available investments).

80. See MCKINSEY \& Co., supra note 77 , at $40-41$ (noting that consumers expect many household efficiency investments to pay off through savings over two to three years, resulting in 
they often opt for cheaper, less efficient models even if more efficient models would pay for themselves within a few years. U.S. tax policy also undermines long-term investments in efficiency, despite some tax credits and other preferential treatment for energy efficient appliances and equipment. ${ }^{81}$ Most importantly, the tax code allows firms to immediately deduct expenses for electricity and fuel purchases, but capital investments in energy-saving equipment must be depreciated over very long time periods (thirty-nine years, in the case of commercial buildings). ${ }^{82}$

These features of energy markets result in a paradox: the marketplace may not adopt energy efficient technology or practices even where firms and consumers could save money by doing so. ${ }^{83}$

These market failures and barriers on the demand side are compounded by the fact that the supply of energy efficient equipment is suboptimally low because firms' research into energy efficiency is a public good. As Nobel Prize winning economist Kenneth Arrow recognized as early as 1962, entrepreneurs will not succeed in capturing full returns on research investments because the resulting knowledge is nonrival and not all knowledge is patentable. ${ }^{84}$ Because research is a positive externality, the market, left to itself, will produce too little private-sector investment in energy efficient technology. ${ }^{85}$

Some form of government intervention is justifiable to correct market failures and overcome these hurdles to energy efficiency. The question is: Which policy tools are best suited for the task? Potentially, governments could deploy a variety of tools other than MEPS, such as product labeling, electricity taxes, a broad carbon tax, or carbon pricing grounded in emissions trading. At first glance, these strategies have several advantages over MEPS.

an implicit discount rate of nearly $40 \%$ ); Sachs, supra note 58 , at 309 ("[C]onsumers have a very low sensitivity to the prospect of a reduction in energy bills even a year or two in the future.").

81. See 26 U.S.C. § 45M (2006) (tax credit for efficient home appliances); § 25D (tax incentives for energy efficient residential properties).

82. Id. $\$ 168(\mathrm{c})$.

83. See Michael Vandenbergh et al., Individual Carbon Emissions: The Low-Hanging Fruit, 55 UCLA L. REV. 1701, 1734 (2008) ("Consumers' extremely high discount rates for longterm savings from one-time purchases tend to serve as a barrier . . . to economically favorable investments in energy-saving devices.").

84. See generally Kenneth Arrow, The Economic Implications of Learning by Doing, 29 REV. ECON. STUD. 155 (1962).

85. See Popp et al., supra note 76, at 3 ("Because of the public goods nature of knowledge, a firm that invests in or implements a new technology typically creates benefits for others while incurring all the costs."); see also Jaffe et al., supra note 28 , at $168-70$. 
First, by disclosing information on product energy consumption or raising the overall price of energy consumption, these demand-side tools could achieve gains in energy efficiency without requiring government officials to engage in product-by-product rulemakings..$^{86}$ They devolve decisionmaking from government agencies to consumers themselves.

Second, energy-pricing strategies could provide incentives for consumers to reduce reliance on energy-using products already in homes and businesses. Product standards, on the other hand, apply only to new products as they are introduced into the market. Relying on a regulatory strategy for promoting energy efficiency inevitably means that there will be several years of capital stock turnover before a newly enacted product standard becomes the prevailing standard for the majority of goods in use..$^{87}$

Finally, MEPS may reduce energy consumption by limiting consumer choice. For example, some consumers may desire a low-cost, inefficient product because of budget constraints that limit upfront expenditures. Consider a low-income family that wants to buy a room air conditioner for use only fifteen to twenty days per year. The family may very well prefer a cheaper, less efficient brand of air conditioner, but MEPS-in setting a minimum floor for efficiency-may force the

86. See Herman Vollebergh, ORg. For Econ. CoOperation \& DeV., Impacts of ENVIRONMENTAL POLICY INSTRUMENTS ON TECHNOLOGICAL CHANGE 7 (2007) ("D]irect regulations may constrain the potential 'space' for innovation, reducing incentives to identify those options that are most cost-effective in the long run.").

87. See Sachs, supra note 58, at 314 (noting that the benefits of performance standards take many years to realize because they apply only to new products). These same issues regarding capital stock turnover arise in the policy choice between increasing Corporate Average Fuel Economy ("CAFE") standards for automobiles and raising gasoline taxes. A gasoline tax affects operating costs for all automobiles in use, whereas CAFE standards affect only new cars being sold into the market. See CONG. BUDGET OFFICE, FUEL ECONOMY STANDARDS Versus A GASOLINE TAX 2 (2004) ("A gasoline tax is a good policy to compare with CAFE standards because it is the most direct way to reduce gasoline consumption. By raising the price of gasoline to consumers, a tax raises the cost of driving and encourages consumers to buy more-fuel-efficient vehicles."); see also Freeman, supra note 4, at 366-68 (analyzing the Obama administration's rulemaking to raise fuel economy standards in the wake of Congress's failure to enact more comprehensive cap-and-trade legislation). Despite the theoretical advantages of a taxation approach to improving efficiency, the United States continues to opt for the regulatory approach, in large part because Congress has been unwilling to raise the federal gas tax, which has remained constant at 18.4 cents per gallon since 1993. Moreover, the public strongly prefers a regulatory approach to a taxation approach. See CHRIS BORICK \& BARRY RABE, BROOKINGS INST., PUBLIC VIEWS OF CLIMATE POLICY OPTIONS 2-5 (2012) (discussing polling data showing that only $6 \%$ of Americans strongly support increases in gasoline taxes, whereas $44 \%$ strongly support the increase in CAFE standards to $54.5 \mathrm{mpg}$ ). 
cheapest products off the market. ${ }^{88}$ Or consider a hypothetical regulation that bans "always on" or "standby mode" capabilities in consumer electronics. This would result in massive energy savings (the United States runs at least eight large power plants just to power equipment that is ostensibly off), 89 but the ban would come at a cost of functionality. Consumers will not want to go back to the days of getting up from the sofa to turn on the television manually.

Of course, MEPS can and should be deployed in tandem with other policies, such as energy-consumption labeling or a cap-and-trade system, to capture the benefits of multiple approaches and raise revenue at the same time (this is the EU policy structure). But MEPS should not be discarded. They have some major advantages that help to explain their persistence in environmental policy throughout the developed world.

In outlining these advantages, it is helpful to compare MEPS to a labeling-only strategy, in which the energy consumption of products would simply be disclosed on a product label. This option has been advocated by Kip Viscusi and other scholars, who have argued that information disclosure is a preferable solution for any market failure or consumer irrationality in energy markets. ${ }^{90}$ After discussing the disclosure alternative, I will compare MEPS to energy-pricing systems for encouraging efficiency, such as energy taxes or a cap-and-trade system.

\section{B. Standards Versus a Labeling-Only Strategy for Efficiency}

One advantage of regulation compared to a labeling-only strategy is that MEPS apply behind the scenes to a limited class of

88. See Kenneth Gillingham, Richard G. Newell \& Karen Palmer, Energy Efficiency Economics and Policy 23 (Res. for the Future, Discussion Paper 09-13, 2009) (" $[\mathrm{P}]$ roduct standards could lead to a loss in economic efficiency by forcing behavior change on those who gain relatively little from energy efficiency (e.g., those who do not use the product often) ....").

89. See Rocky MOUNTAIN INST., ReInVENTING FIRE 83 (2011); see also Pulling the Plug on Standby Power, ECONOMIST, Mar. 9, 2006, http://www.economist.com/node/5571582 (noting that standby electronics may account for as much as $13 \%$ of residential energy consumption). In many cases, products consume more power while switched off, due to the fact that many electronics are switched on for only a few hours a day. REAL PROSPECTS REPORT, supra note 1, at 86 . The issue of standby power and always-on capability will become even more pressing as homeowners install home networks in which products must remain on to remain connected to the network. $I d$.

90. Ted Gayer \& W. Kip Viscusi, Overriding Consumer Preferences with Energy Regulations 11 (Mercatus Ctr., No. 12.21, 2012), available at http://mercatus.org/publication overriding-consumer-preferences-energy-regulations ("Even if such behavioral biases are leading to inefficient energy decisions by consumers, providing accurate information to consumers would be preferable to regulatory mandates."). 
manufacturers, rather than to hundreds of millions of consumers. As such, MEPS do not depend on consumers having a detailed understanding of energy pricing and energy usage. A labeling-only strategy, in contrast, depends entirely on consumers' ability to trade off capital equipment costs and long-term operational costs. But the lack of consumer understanding of energy pricing (particularly electricity pricing) is a serious hurdle to reliance on product labeling as the primary tool to promote efficiency. Electricity prices, unlike gasoline prices, vary by the hour, and consumers are usually unaware of these swings in prices. The argument that labels alone will help consumers determine the optimal trade-off between purchase price and long-term operational costs ignores this reality of the market. Product standards, in contrast, avoid many of these informational problems that plague markets for efficient equipment, ${ }^{91}$ and they prevent the worst-performing products from reaching the market at all.

A labeling strategy also shifts substantial search costs to consumers and necessitates that the consumer act as the key decisionmaker in this segment of national climate policy. Information disclosure is an important complement to regulation in energy efficiency policy. ${ }^{92}$ But, standing alone, labeling initiatives can simply be a cheap means for government officials to abdicate their responsibility to protect public health and the environment. As Doug Kysar has explained, product-labeling strategies can unjustifiably put the consumer in a "heroic" role in which governments avoid making hard choices and instead place the burden on consumers to comprehend complex risks or to shift a market toward environmentally friendly technologies. ${ }^{93}$ But if consumers are not tracking the labels, do not understand the labels, or become overwhelmed by the search costs involved, government will have abdicated responsibility with no other actor to take up the slack.

91. See Richard B. Howarth \& Alan H. Sanstad, Discount Rates and Energy Efficiency, 13 CONTEMP. ECON. POL'Y 101, 108 (1995) ("D]irect regulation of equipment performance might side-step problems of asymmetric information, transaction costs, and bounded rationality, obviating the need for individual consumers to make unguided choices between alternative technologies.").

92. See, e.g., ElLIS, supra note 3, at 20 (MEPS and product labeling laws are "complimentary" because "the former removes the worst performing products, while the latter promotes the better ones").

93. See Douglas A. Kysar, Preferences for Processes: The Process/Product Distinction and the Regulation of Consumer Choice, 118 HARV. L. REV. 525, 635 (2004) (criticizing development of environmental policy based on revealed consumer preferences, because such policy transforms the consumer's role into an "unwitting mechanism for collective valuation"). 
Product efficiency regulation, on the other hand, represents a governmental judgment on feasible improvements in energy efficiency, bars the least efficient products from the market, and avoids "the need for every individual to undertake the information and assessment process inherent in trading off capital and energy operating costs."94

A second advantage of MEPS compared to a labeling strategy is that consumers tend to have very high "hurdle rates" in their purchases of major equipment; 95 they demand rates of return on efficiency investments that are much higher than prevailing market interest rates in an economy. Therefore, even if a product label could somehow disclose, based on prevailing energy prices, that higher prices for efficient equipment could be recouped within one or two years, many consumers would still opt for a product with a lower upfront cost. MEPS help to overcome this important barrier to the diffusion of energy efficient equipment.

Finally, energy-consumption labels are not likely to be effective in situations where the purchaser of the product is not the ultimate user, as in the landlord-tenant situation. MEPS have sometimes been criticized for saddling low-income consumers with higher upfront costs, ${ }^{96}$ but for millions of tenants paying utility bills, the standards help to ensure lower operating costs for products that were not of the tenant's own choosing. ${ }^{97}$

\section{Standards Versus an Energy-Pricing Strategy for Efficiency}

In comparing product regulation to a carbon tax or cap-andtrade system, I focus specifically on the effects of these alternative policies on energy consumption from energy-using equipment. I do not presume that MEPS could have the same far-reaching economic and environmental effects as these alternative policies. While studies by the ACEEE and other organizations have concluded that product

94. Jaffe et al., supra note 28, at $\mathbf{1 7 2 .}$

95. See Adam B. Jaffe \& Robert N. Stavins, The Energy Efficiency Gap: What Does It Mean?, 22 ENERGY POL'Y 804, 806-07 (1994) (discussing the high rates of return consumers expect on investments in energy efficient technology).

96. See Ronald J. Sutherland, The High Costs of Federal Energy Efficiency Standards for Residential Appliances, POL'Y ANALYSIS (Cato Inst., Washington, D.C.), Dec. 23, 2003, at 11 ("Appliance standards impose an economic burden that weighs particularly heavily on low- and middle-income people."); see also Michael P. Vandenbergh \& Brooke A. Ackerly, Climate Change: The Equity Problem, 26 VA. ENVTL. L.J. 55, 56 (2008) (noting potential higher costs resulting from appliance efficiency standards).

97. See Sachs, supra note 58, at 307 (32\% of American households are rentals, and tenants pay utility bills in over $80 \%$ of these units). 
efficiency regulations can reduce U.S. energy consumption by $3 \%$ to $7 \%$ from projected business-as-usual conditions, a serious climate change mitigation strategy requires a $50 \%$ to $85 \%$ reduction in global greenhouse gas emissions by midcentury. Clearly, efficiency regulations are only one piece of the mitigation puzzle. I have argued in favor of carbon pricing elsewhere, ${ }^{98}$ and there is no doubt that a robust strategy to "green" energy demand needs to be economy-wide, rather than focused on particular products.

The real question, therefore, is whether pricing strategies, assuming they were implemented, would obviate the need for product efficiency regulation. Could higher energy prices alone drive technological change toward highly efficient products? As with product standards and labeling, there are strong arguments for implementing a tandem approach that would retain the policy architecture of product standards, even under a carbon pricing system.

One advantage of product standards is that they have a global reach. Because all manufacturers must comply with the standard to sell in a major market such as the United States or the EU, the standards can have the effect of upgrading the efficiency of internationally traded goods. Furthermore, when a large jurisdiction enacts product standards for energy efficiency, it makes it easier for other jurisdictions to enact tough efficiency standards-the so-called "California effect." 99 In contrast, national carbon pricing does little to reduce energy consumption outside the borders of the enacting jurisdiction.

The most significant advantage of product efficiency standards is that they guarantee improvements in energy efficiency and force the worst-performing products off the market. The energy savings from MEPS are predictable, relatively easy to quantify, and can be verified after the fact.

In contrast, a carbon pricing approach may have only negligible effects on greenhouse gas emissions associated with energy-using products. Scholars have begun to question the widely held assumption that carbon pricing alone can promote climate-friendly technological and behavioral change. ${ }^{100}$ To promote that change, a carbon price

98. Id. at 306 ("Putting a price on carbon emissions, through a carbon tax or cap-and-trade system, is the single most important policy change that would move the United States away from wasteful energy consumption habits.").

99. See DAvid Vogel, TRAding Up: Consumer and ENVIRonMental REgUlation in a GLOBAL ECONOMY 248-70 (1997) (discussing the "California effect" for globally traded goods).

100. See David M. Driesen, Free Lunch or Cheap Fix? The Emissions Trading Idea and the Climate Change Convention, 26 B.C. ENVTL. AFF. L. REV. 1, 42-43 (1998) (questioning the 
(paid, for example, by gas distributors or electric utilities) would have to be high enough to raise retail prices for natural gas or electricity, to influence the behavior of consumers and firms, and to drive the purchasing decisions of millions of consumers and firms toward energy efficient products. But household energy demand is price inelastic-at least in the near term ${ }^{101}$-and with the notable exception of automobiles, energy costs are a minor factor in most consumers' purchasing decisions. Moreover, most carbon pricing policies proposed to date would have only negligible impacts on the operating costs of most household and commercial equipment. Any pricing strategy would run headlong into the market failures and market barriers discussed above that make energy prices an unreliable driver of technological change in energy-using products. ${ }^{102}$

Above, I discussed the problem of consumers' lack of awareness about the energy usage of particular products. Here, I contend that even if consumers had perfect information about their monthly energy usage, the energy usage of particular products, and projected energy prices under a cap-and-trade or carbon tax regime, consumers would still not care enough about small policy-driven changes in energy prices to change their purchasing or usage habits. ${ }^{103}$

Advocates of carbon pricing as a way to promote technological innovation rarely address the cognitive issue of how small price increases for electricity or natural gas will enter consumers' awareness and affect the products they buy or the amount of energy they use. ${ }^{104}$ With a new abundance of natural gas in the United

commonly held view that cap-and-trade systems promote technological innovation); Klaus Rennings, Redefining Innovation - Eco-innovation Research and the Contribution from Ecological Economics, 32 ECOLOGICAL ECON. 319, 325 (2000) (noting that the innovation impacts of tax-based energy-pricing strategies "may be watered down in the political process"); Michael P. Vandenbergh, Amanda R. Carrico \& Lisa Schultz Bressman, Regulation in the Behavioral Era, 95 MINN. L. REV. 715, 765 (2011) (criticizing policies aimed at reducing household energy consumption for "reflect[ing] strong assumptions about the influence of price and thus often overlook[ing] other influences on behavior").

101. See Bengt Kriström, Residential Energy Demand, in HOUSEHOLD BEHAVIOUR AND THE ENVIRONMENT: REVIEWING THE EVIDENCE 95, 102 (2008) (“[R]esidential energy consumption in the short term is one of the most inelastic goods in the economy.").

102. See Vandenbergh et al, supra note 83 , at 1755 ("NN]umerous empirical studies demonstrate that in practice, limited information, high transaction costs, and a wide range of behavioral phenomena limit the extent to which price alone affects behavior.").

103. See Vandenbergh \& Steinemann, supra note 15, at 1725 (discussing the irrationality of consumers in their energy-consuming behaviors); see also id. at 1698 (noting barriers to behavioral change even where the benefits of the change clearly outweigh the costs).

104. See Paul C. Stern, Blind Spots in Policy Analysis: What Economics Doesn't Say About Energy Use, 5 J. POL'Y ANALYSIS \& MGMT. 200, 203 (1986) (criticizing economic models of energy 
States, electricity and natural gas prices are expected to remain low for the foreseeable future. ${ }^{105}$ Moreover, in practice, the signaling effect of many cap-and-trade systems is diluted due to political pressure to keep energy prices stable. For example, the Waxman-Markey cap-andtrade bill, which passed the U.S. House of Representatives in 2009, contained numerous provisions, including free distribution of emissions allowances, to ensure that retail consumers would not see any significant energy price increases from the legislation. ${ }^{106}$

In short, there is simply insufficient market "pull" for efficiency, in the form of consumer demand, to encourage the rapid technological transformations needed to address the climate crisis. That pull is unlikely to be generated by economy-wide cap-and-trade systems or by carbon taxes, unless the carbon price is substantial (above $\$ 80$ per ton). A regulatory approach, by contrast, has the potential to "push" efficient technologies even if retail energy prices are low and even if consumers are not cognizant of the long-term operational costs of equipment.

I do not mean to imply that regulation is always necessary to promote energy efficient products in the marketplace. Major energy users in the industrial, transportation, and building sectors already have enormous financial incentives to reduce energy consumption even without any governmental efficiency "push." Google, for example, has worked for years to reduce energy consumption in its server farms, ${ }^{107}$ and large commercial tenants seeking office space often prefer highly efficient buildings. But at the retail level, where consumers ordinarily are not paying attention to the energy usage of products they buy, product standards should be maintained and expanded to drive efficiency improvements.

Time is running very short for nations to address the climate crisis, and the transition toward low-carbon, highly energy efficient

policy that "make strong assumptions about price responses [of consumers] that probably distort the cognitive processes that mediate those responses").

105. U.S. ENERGY INFO. AdMIN., SHORT TERM ENERGY OUTLOOK 1, 9 (2012) (noting that natural gas inventories in May 2012 were $31 \%$ higher than the previous year and that natural gas prices are at "historically low levels"). The EIA also projected a $2.8 \%$ drop in retail electricity prices by 2013 , due primarily to a decrease in natural gas costs for electricity generators. Id. at $10-11$.

106. See American Clean Energy and Security Act of 2009, H.R. 2454, 111th Cong. $§ 783$ (2009) (as passed by the House June 26, 2009) (requiring that allowances be provided to electricity distributors to keep retail electricity prices stable).

107. See Google's Green Computing: Efficiency at Scale, GoOGLE, http:/static. googleusercontent.com/external_content/untrusted_dlcp/www.google.com/en/us/green/pdfs/google -green-computing.pdf (last visited Sept. 5, 2012). 
economies must begin this decade. When it comes to speed of implementation, product standards have clear advantages over other policy tools to promote efficiency, especially in the United States, where national carbon taxes or a cap-and-trade system are off the political agenda. The legislative and administrative infrastructure for enacting product standards is already in place on both sides of the Atlantic, and MEPS have a track record of success. Moreover, in opinion polling, Americans actually prefer regulatory approaches over market-based approaches to climate change. For example, Americans favor national renewable portfolio standards and the Environmental Protection Agency's greenhouse gas emissions regulations compared to fossil fuel taxes or a cap-and-trade system. ${ }^{108}$

Ideally, governments should deploy a mix of policy tools, each targeting different parts of the problem of escalating energy demand. California and New York, for example, have used a mix of energy efficiency tools to keep per capita electricity consumption flat since about 1970.109 The EU has also deployed multiple policy tools to promote energy efficiency and climate change mitigation. The EU relies on MEPS, product labels, gasoline taxes, and a cap-and-trade system to achieve an EU-wide goal of reducing greenhouse gas emissions to $20 \%$ below 1990 levels by 2020 . But in the United States, the prospects for a national carbon tax or a cap-and-trade system are highly remote. This leaves efficiency regulation as one of the few remaining, politically acceptable strategies to reduce energy demand in the United States. ${ }^{110}$

\section{Avoiding the Pitfalls of Regulation}

As the United States and the EU expand their standards for product efficiency, critics are charging that the standards go too farthat they interfere with consumer choice and are overly stringent or prescriptive. ${ }^{111}$ As the Competitive Enterprise Institute charged,

108. See BORICK \& RABE, supra note 87, at 1-2.

109. See REAL PROSPECTS REPORT, supra note 1, at 279-89 (analyzing methods used by New York and California to minimize per capita electricity consumption).

110. See Jaffe et al., supra note 28, at 169 (noting that in the absence of carbon pricing in the United States, we are in a "second-best" setting in which "policy to foster greenhouse-gasreducing technology may be one of the main policy levers available and can be justified on economic grounds so long as it has positive net benefits").

111. See, e.g., Sutherland, supra note 96 , at 12 (noting that government regulation increases price and forces choices upon consumers, especially the poor); Gayer \& Viscusi, supra note 90 , at 2 (Efficiency standards "assume consumers and, in some cases, firms are incapable of making rational decisions and that regulatory policy should be governed by the myopic objective of 
efficiency standards put an "annoying regulation in every room in the house." 112 Product efficiency standards are prone to the informational and bureaucratic pitfalls of any regulation, and the challenge for policymakers is how to ensure smart regulatory design that does not significantly disrupt product innovation or the consumer experience.

It would be easy to conceive of overly stringent or poorly designed product standards that could damage whole industries. Imagine, for example, that the United States had established an efficiency standard for cell phones in 1999 requiring that cell phones use $60 \%$ less energy by 2007 . Such a standard would have undoubtedly saved energy, but it would also have killed the market for smart phones-with their larger screen sizes and larger energy consumption-and would have hindered innovation in this fastmoving industry. ${ }^{113}$ Governments, therefore, need to be particularly sensitive to the innovation effects of standards, avoid standards for products with very short development cycles, work in close cooperation with industry stakeholders, and revisit standards frequently.

In the view of many scholars, trying to craft product standards that are compatible with innovation is a fool's errand because centralized regulation of product performance is fundamentally antithetical to technology innovation. ${ }^{114}$ The traditional critique of command-and-control environmental regulation, dating to the 1970s, holds that prescriptive governmental regulation is ineffective because (1) government is likely to do a poor job of promoting technological change in a marketplace, (2) government is likely to make politically motivated decisions benefiting favored firms, (3) command-and-control regulation is homogeneous and rarely takes into account different capabilities of firms to reduce emissions or innovate, (4) the private sector is better positioned to gather and act on information regarding

energy efficiency to the exclusion of other product attributes."); Ben Lieberman, An Annoying Regulation for Every Room in the House, BLOG OF COMPETITIVE ENTERPRISE INST. (Sept. 24, 2010), http://www.openmarket.org/2010/09/24/an-annoying-regulation-for-every-room-in-thehouse/ ("The only thing federal regulations accomplish is to force the government's preferred choice on everyone.").

112. Lieberman, supra note 111.

113. See Megan Geuss, Why Your Smartphone Battery Sucks, PCWORLD (May 18, 2011), http://www.pcworld.com/article/228189/why_your_smartphone_battery_sucks.html (noting that rapid development of smart phone technology and related increases in energy consumption are outpacing battery development).

114. Richard B. Stewart, Regulation, Innovation, and Administrative Law: A Conceptual Framework, 69 CALIF. L. REV. 1256, 1279-80 (1981) (outlining why regulation can disrupt or slow innovation and arguing that the delay in firms' innovation associated with meeting regulatory requirements reduces returns on investment and therefore contributes to a "comparative advantage of existing products and processes"). 
technological possibilities for pollution control, and (5) prescriptive performance standards provide no reward for firms to innovate to exceed the standard. ${ }^{115}$

In the particular case of energy efficiency standards, critics have charged that they impose unwarranted technical constraints on product design, performance, or function and force firms to divert R\&D resources into regulatory compliance-a diversion that carries significant opportunity costs.116 Moreover, critics contend, federal product standards cause regulatory uncertainty and potential delays in moving innovative products to market. As Douglas Johnson, senior director of technology policy at the Consumer Electronics Association put it: "Mandates ignore the fundamental nature of the industry that innovates due to consumer demand and technological developments, not regulations."117

Governments now have a thirty-year track record with MEPS, however, and there is little evidence that MEPS have disrupted innovation in regulated industries. From refrigerators to dishwashers to televisions, energy-using products have become cheaper, more efficient, and more feature-packed over time. ${ }^{118}$ Lighting efficiency

115. See Timothy F. Malloy, The Social Construction of Regulation: Lessons from the War Against Command and Control, 58 BUFF. L. REV. 267, 283-88 (2010). Malloy helpfully groups the standard critiques of command and control regulation into three categories: rigidity, homogeneity, and competency. Id. For examples of the standard critique of command and control regulation, see sources cited by Malloy, id. at 284-87 nn.49-61. See also Bruce A. Ackerman \& Richard B. Stewart, Reforming Environmental Law, 37 STAN. L. REv. 1333, 1335 (1985) ("Uniform [technology] requirements waste many billions of dollars annually by ignoring variations among plants and industries in the cost of reducing pollution and by ignoring geographic variations in pollution effects."); Stewart, supra note 114, at 1282 (noting that regulated industries are "likely to have a far greater working knowledge of the products or processes sought to be transformed than the regulating agency," and accordingly, regulated industries are in a strong position to challenge standards through litigation); Richard B. Stewart, Economics, Environment, and the Limits of Legal Control, 9 HARV. ENVTL. L. REV. 1, 6-9 (1985) (contending that command and control regulation encourages wasteful practices, discourages innovation, and largely fails at spurring new technology).

116. See Stewart, supra note 114, at 1280 (noting that command-and-control regulation forces firms to divert resources into compliance and to divert management attention to regulatory matters, which "may involve substantial opportunity costs"); see also Nicholas A. Ashford, George R. Heaton \& W. Curtiss Priest, Environmental Health and Safety Regulation and Technological Innovation, in TECHNOLOGICAL CHANGE FOR A DYNAMIC ECONOMY 161, 172 78 (Christopher T. Hill \& James M. Utterback eds., 1st ed. 1979) (outlining potentially disruptive effects of regulation on firms' research and development efforts, management, and competitiveness).

117. Jad Mouawad \& Kate Galbraith, Plugged In Age Feeds a Hunger for Electricity, N.Y. TIMES, Sept. 19, 2009, at A1.

118. See REAL PROSPECTS REPORT, supra note 1, at 50 (the average new refrigerator sold in the United States in 2007 used about $498 \mathrm{kWh}$ per year, $71 \%$ less than the average electricity 
standards enacted by Congress in 2007, discussed in more detail in Part III, provide a recent example of how efficiency regulation can be consistent with, and even promote, product innovation. When Congress first enacted the standards, critics widely feared that they would amount to a ban on incandescent light bulbs and a de facto mandate for compact fluorescent bulbs. ${ }^{119}$ These fears proved to be unfounded, however. By 2010, manufacturers had adapted to the standards both by promoting compact fluorescent bulbs and by developing a new generation of efficient incandescent bulbs that complied with the standards. ${ }^{120}$ In other words, the new standards led to manufacturer innovation and more consumer choice in the market, not less.

The debate over whether product efficiency standards promote or hinder innovation is really a microcosm of a much larger debate over whether environmental regulation can promote technological innovation or whether it inevitably hinders it. There is now a wealth of economics and business scholarship on this issue, with few consistent results or conclusions. ${ }^{121}$ One barrier to teasing out clear cause-and-effect relationships is that "innovation" is notoriously difficult to quantify. Those studies that attempt to quantify it (through tracking patent applications in pollution control, for example) often overlook that firms can make environmental improvements in response to regulation through subtle operational changes or through changing inputs, rather than through adding novel, patentable, endof-pipe technology. Therefore, studies that look only at patents in examining responses to regulation may underestimate the true amount of industrial innovation that is occurring.

Even defining a regulation is difficult, because a regulation is more than its text. The impact of a regulation is also a function of the comparative stringency of the regulation, firms' awareness of the regulation, the expected likelihood of enforcement, and the potential penalties for noncompliance.

Given the lack of clear conclusions from empirical studies, regulatory critics continue to charge that government regulation will

used by a new refrigerator sold thirty years earlier, though refrigerators became larger and offered more features in that time period).

119. See Leora Broydo Vestel, New Light in Old Bulbs, N.Y. TIMES, July 6, 2009, at B1 (noting the widespread belief that incandescent bulbs would disappear because no traditional incandescent bulbs could meet Congress's new efficiency standards).

120. Id.

121. For a survey of this literature, see generally Rene Kemp \& Serena Pontoglio, The Innovation Effects of Environmental Policy Instruments, 72 ECOLOGICAL ECON. 28 (2011). 
cap innovation and squelch industries, whereas advocates contend that government standards actually incentivize industry to innovate (the so-called "Porter hypothesis," after pioneering work in the early 1990s by Michael Porter). ${ }^{122}$ The truth is probably somewhere in between, and much depends on the details of regulatory design. Government regulation is best viewed as a shaper of ongoing technological development, rather than as a trigger to start it or a bludgeon to stop it. ${ }^{123}$ The innovation pathway of a firm is dependent on so many factors, including R\&D budgets, advances in basic science, international competition, access to capital, and engineering skill. Governmental standards are just one component of this larger ecosystem.

In the debate over regulation and innovation, critics and advocates of product standards are often talking past each other. They are using the term "innovation" in two different senses. There is little evidence that product standards hamper the overall pace of technological innovation in an economy. On the other hand, it is quite clear from empirical studies that product standards can promote innovation in technology to save energy or reduce pollution (patents in pollution-control equipment are one example). ${ }^{124}$ In this more limited sense, product standards can promote innovation in energy efficient heating, cooling, lighting, and computing equipment on a global basis.

Moreover, product standards clearly assist in the important goal of diffusion of energy efficient equipment throughout a market, by prohibiting competition from low-cost, energy-hogging products. ${ }^{125}$

122. See Adam B. Jaffe, Richard G. Newell \& Robert N. Stavins, The Induced Innovation Hypothesis and Energy-Saving Technological Change, 113 Q.J. ECON. 941, 941-43 (1999) (providing background on the induced innovation theory); Porter \& Van Der Linde, supra note 29 (outlining the various ways that government regulation can promote technology innovation); Vernon W. Ruttan, Induced Innovation, Evolutionary Theory and Path Dependence: Sources of Technical Change, 107 ECON. J. 1520, 1520-22 (1997).

123. See Adam B. Jaffe, Richard G. Newell, \& Robert N. Stavins, Environmental Policy and Technological Change, 22 ENVTL. \& RESOURCE ECON. 41, 61 ("[E]nvironmental policy interventions themselves create new constraints and incentives that affect the process of technological developments.").

124. For discussion of studies confirming that command-and-control regulation does stimulate technological change, particularly as measured by filing of new patents, see VOLLEBERGH, supra note 86 , at $19-20$.

125. Joseph Schumpeter maintained that new ideas permeate a market in three distinct phases: invention (the idea of a new business or technological possibility), innovation (the commercial introduction of the new idea), and diffusion (the gradual adoption by firms and individuals of the innovation). JOSEPH SCHUMPETER, CAPITALISM, SOCIALISM, AND DEMOCRACY 132 (1942). Because product performance standards are typically based on the best-performing products currently in use, they are most relevant to the diffusion stage of this process, rather than to invention or innovation. 
Technology diffusion is critically important for climate policy, because the ultimate test of whether any new product innovation makes a difference in reducing energy demand is its degree of market penetration. ${ }^{126}$ Barriers to technology diffusion are particularly potent for climate-friendly technologies, because, as discussed above, consumers tend to choose products based on features and price, not on marginal increases in energy efficiency. A regulatory push, in which MEPS are set by law and noncompliant products can no longer be sold, can help to overcome these barriers.

The challenge for policymakers, therefore, is how to implement product standards in a way that is consistent with continued product innovation. Sophisticated regulatory design can help to avoid some of the traditional pitfalls of command-and-control regulation. ${ }^{127}$ Most importantly, regulations for energy efficiency should be based on performance standards, without dictating that manufacturers adopt specific technologies. A design standard, which mandates use of a particular technology to achieve efficiency goals, essentially forecloses any alternative technology-a brake on innovation. A performance standard, on the other hand, can be satisfied through multiple technologies and still allows firms to compete and innovate, both on features and price.

Policymakers should also avoid product standards that are technology forcing-that is, standards that require reductions in energy use beyond anything manufacturers can currently achieve. Environmental law scholars have often touted technology-forcing regulation to drive innovation, on the grounds that tough mandates can kick-start R\&D. Scholars have pointed to several successful examples of technology-forcing regulation in environmental law, including regulation of industrial and automobile emissions. ${ }^{128}$ Drawing on that track record, some scholars have suggested that the climate crisis is so severe that government regulation should be hyperstringent-forcing substantial technological improvement and

126. See EVERETT M. ROGERS, DIFFUSION OF INNOVATIONS 6 (2003) (defining diffusion as a form of social change by which "alteration occurs in the structure and function of a social system").

127. See Stewart, supra note 114, at 1284 (criticizing the view that there is inexorable conflict between promoting social innovation such as environmental performance and promoting firm profitability).

128. See, e.g., Thomas O. McGarity, Radical Technology-Forcing in Environmental Regulation, 27 LOY. L.A. L. REV. 943, 956-58 (1994) (suggesting that technology-forcing regulation is, in many contexts, preferable to other regulatory tools in environmental law); Stewart, supra note 113 , at 1267 (linking technology-forcing regulation to the further development and adoption of technology). 
eliminating and/or replacing dominant firms that rely on "undesirable technologies."129

Governments should tread carefully in the context of product standards, however, given that the standards will be applied to fastmoving industries and to billions of products in an economy. Product regulation should not involve "shock treatment" for manufacturers, ${ }^{130}$ and, as a matter of politics, it is unrealistic to think that federal or state governments would ever deploy product standards to eliminate dominant firms in an economy. Moreover, as a matter of regulatory design, technology-forcing regulation for the environment involves the difficult task of judging, ex ante, how far regulation can push technology. As Adam Jaffe and his colleagues have concluded, "while regulators can typically assume that some amount of improvement over existing technology will always be feasible, it is impossible to know how much." Therefore, technology-forcing product standards "run the risk of being ultimately unachievable ...."131

The approach taken in the United States and the EU of close consultation with industry to negotiate incremental improvements in the existing energy performance of products is quite sensible. If product standards were to become technology forcing, imposing requirements that no actor in the industry can currently meet, government runs the risk of blundering into costly and anticompetitive standards. Moreover, the implementation of product standards depends on manufacturer cooperation, and promoting incremental improvement helps to ensure that cooperation over the long term. Although it is tempting to wring massive energy savings out of products by regulatory fiat, such stringent, better-than-best regulation risks losing long-term political support for the programs.

Adverse effects on manufacturers can also be minimized by allowing at least two years of compliance lead time and involving multiple stakeholders in the planning process for standards. Moreover, to provide incentives for manufacturers to exceed minimum standards, governments should promote energy-labeling and certification programs (such as Energy Star in the United States and the flower eco-label in the European Union) for the best-performing

129. Nicholas A. Ashford \& Ralph P. Hall, The Importance of Regulation-Induced Innovation for Sustainable Development, 3 SUSTAINABILITY 270, 278 (2011).

130. Int'l Harvester Co. v. Ruckelshaus, 478 F.2d 615, 648 (D.C. Cir. 1973) (discussing technology-forcing automobile emissions regulations in the 1970 Clean Air Act).

131. Adam B. Jaffe, Richard G. Newell, \& Robert N. Stavins, Technological Change \& the Environment, in 1 HANDBOOK of ENVIRONMENTAL ECONOMiCS 461, 477 (K.-G. Mäler \& J.R. Vincent eds., 2003). 
products on the market. In this way, regulatory standards force the worst-performing products off the market, while the labeling and certification programs help to promote the best-performing products above the minimum efficiency threshold.

All climate change mitigation policies involve trade-offs. MEPS do, in the end, reduce both manufacturer and consumer freedom in the marketplace. That is the nature of this kind of regulatory intervention. But MEPS can nonetheless be justified because of market failures and because of externalities that turn individual consumers' energy consumption into a collective escalation in energy demand that speeds climate disruption. Ultimately, the desirability of expanding a regulatory strategy to reduce greenhouse gas emissions depends on one's views of the seriousness of the climate change problem. If we simply ignore climate impacts from energy consumption, then the case for government intervention to regulate product performance becomes far weaker. But MEPS become essential if we take scientists' recommendations seriously: that we need to use every deployable policy tool to achieve $50 \%$ to $85 \%$ reductions in greenhouse gas emissions by midcentury. ${ }^{132}$ To make that transition to a low-carbon economy, the United States and other nations need to become vastly more efficient in the way they power their economies.

\section{III.THE TASK AHEAD}

Looking forward, the challenge of expanding product efficiency standards is twofold. First, there is a technical challenge: getting the standards right and deciding which product classes should be subject to standards. Second, there is a political challenge: maintaining support for product efficiency standards in the face of increasingly strong opposition. Below, I consider both challenges for the future of product efficiency standards.

\section{A. The Future Technical Potential for Product Standards}

The best recent analysis of the potential for future expansion of MEPS in the United States has been performed by the ACEEE. In a

132. See Intergovernmental PANEL on Climate Change, Fourth Assessment RePort: Climate Change 2007: Working Group III: Mitigation of Climate Change 423-25 (2007) (providing examples of MEPS and discussing their effectiveness in reducing greenhouse gas emissions); NoBUo TANAKA, INT'L ENERGY AGENCY, WORLDWIDE IMPLEMENTATION NOW: THE ESSENTIAL ROLE OF ENERGY EFFICIENCY 2-5 (2008) (citing energy efficiency as a necessary and effective means for combating climate change). 
March 2012 report, the ACEEE showed that feasible new standards for thirty-four product categories could shave an additional 7\% off U.S. electricity consumption by 2035 compared to current projected trends and would also save consumers almost $\$ 170$ billion (in net present value 2010 dollars) over the same time frame. ${ }^{133}$ Some of these savings come from updating older standards (such as existing standards for clothes washers), and some come from establishing new standards for products that have become large components of energy use (such as cable set-top boxes, motors, furnace fans and blowers, and commercial refrigeration equipment). ${ }^{134}$ The following chart illustrates future electricity savings from realistic expansion of MEPS in the United States.

133. LOWENBERGER ET AL., supra note 22, at v-vii.

134. Id. at vii tbl.ES-2. 
The Effect of Standards on Total U.S. Energy Consumption ${ }^{135}$

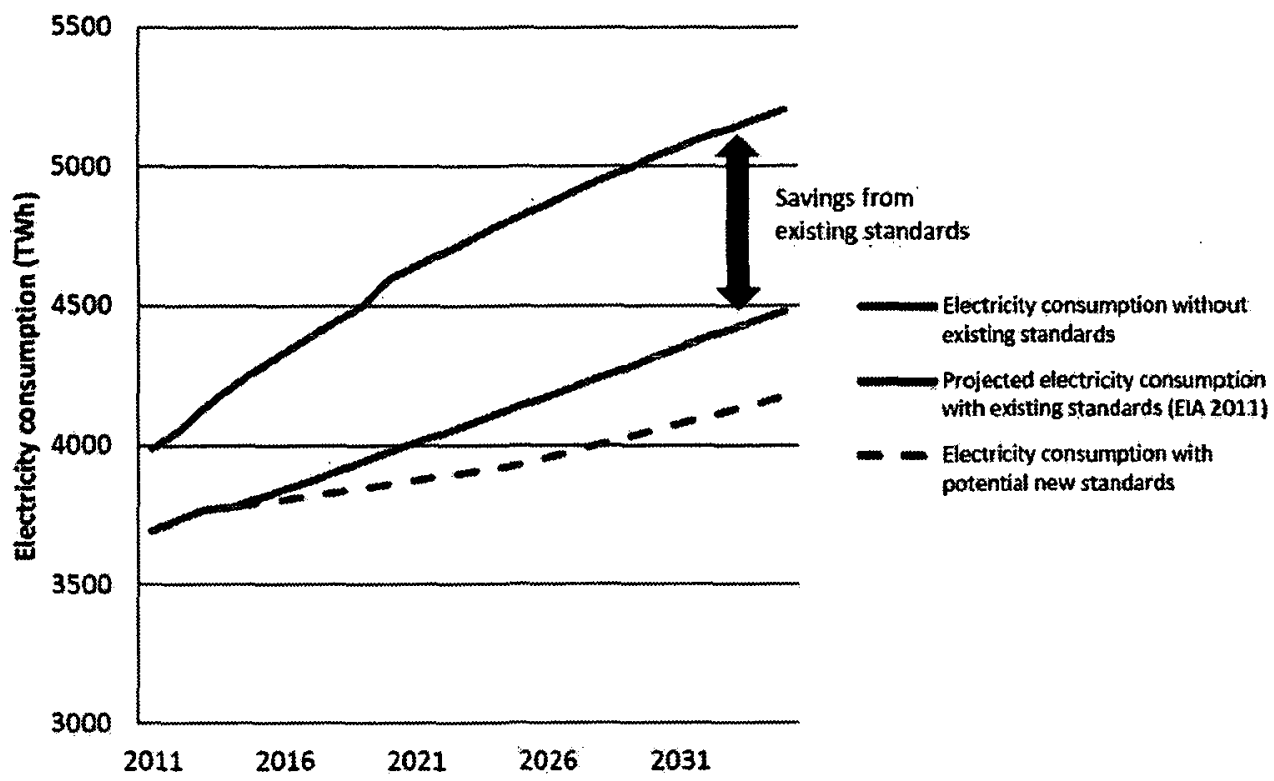

The ACEEE study suggests that there is ample room for expanding MEPS in the coming years. For example, it shows that significant savings could be obtained from cable set-top boxes and video game consoles (through a requirement that these devices default to a low-power mode when not in use). ${ }^{136}$ And it shows significant savings from computer equipment, microwave ovens, and other products (through promulgating MEPS equivalent to current Energy Star-labeled products). ${ }^{137}$ DOE has already undertaken preliminary analyses of standards for many of the products in the report, such as commercial furnaces and commercial refrigeration. ${ }^{138}$ Barring repeal of the underlying statutes or curtailment of DOE's authority, at least a dozen new U.S. MEPS are likely to be enacted this decade.

In Europe, the European Commission is currently conducting preparatory studies for additional product standards under the EcoDesign Directive, and the standards are expected to be finalized by

135. Id. at iii.

136. Id. at $29-31$.

137. Id. at $27-31$.

138. Energy Conservation Standards for Commercial Refrigeration Equipment: Public Meeting and Availability of the Preliminary Technical Support Document, 76 Fed. Reg. 17,573 (Mar. 30, 2011). 
2015. Covered products include industrial furnaces, machine tools, outdoor lighting, and central heating equipment. ${ }^{139}$

As noted above, there are limits to what governments can achieve by expanding MEPS in the coming decades. MEPS cannot guarantee absolute reductions in energy consumption. MEPS can promote more efficient refrigerators, but they cannot change consumers' desires for ever-larger refrigerators, or their decisions to run two refrigerators in a household. ${ }^{140}$ And product standards, while promoting equipment efficiency, do little to do promote systems efficiency. For example, standards can lead to adoption of more efficient light bulbs, but they do not provide incentives to design buildings that rely on daylighting of offices rather than artificial light bulbs. For these larger, systemic changes, other policies are necessary, such as energy efficient building codes, carbon pricing, and smarter land use regulation. ${ }^{141}$

Global energy consumption is ultimately a function of population growth, economic growth, new energy-using technologies, diffusion of efficiency measures, and consumer preferences and habits. It is asking far too much of incremental product standards to judge MEPS a success only if they reduce absolute global energy consumption. The function of MEPS is more limited: achieving marginal reductions in energy demand as one of many strategies for climate change mitigation.

\section{B. The Political Viability of Product Standards}

The other major challenge for product standards as climate change policy is how to ensure political support. In the United States, MEPS have enjoyed relatively strong political backing. The major U.S. energy efficiency statutes were signed by President Ronald Reagan, President George H.W. Bush, and President George W. Bush, ${ }^{142}$ and

139. ARne REMmen, RikKe Dorothea ANDERSEn \& Carl DalHammar, EXPanding the SCOPE OF THE EUP DIRECTIVE 38-39 (2011).

140. See U.S. DEP'T OF ENERGY, REFRIGERATOR MARKET PROFILE 1 (2009) (noting that $26 \%$ of all U.S. households have two refrigerators).

141. For recent work discussing how to promote more systemic changes in land use, architecture, information systems, and transportation to promote energy efficiency, see generally Neal Elliott, Maggie Molina \& Dan Trombley, AM. Council for an ENERgy-EFficient ECONOMY, A DEFINING FRAMEWORK FOR INTELLIGENT EFFICIENCY (2012), available at http:/ /www.aceee.org/sites/default/files/publications/researchreports/e125.pdf; LovINS, supra note 1.

142. President Reagan signed the National Appliance Energy Conservation Act of 1987, Pub. L. No. 100-12, 101 Stat. 103 (codified at 42 U.S.C. $\$ \$ 6291-6309$ (2006)) and the National Appliance Energy Conservation Amendments of 1988, Pub. L. No. 100-357, 102 Stat. 671. 
Congress enacted them on a bipartisan basis. For example, the National Appliance Efficiency Conservation Act of 1987 passed the Senate $89-6$ and passed the House on a voice vote. ${ }^{143}$ The Energy Independence and Security Act of 2007, which contained light bulb efficiency standards, passed the House 314-100 and the Senate 86$8 .{ }^{144}$

Recently, however, U.S. efficiency standards have come under attack. The efficiency standard for light bulbs has become symbol on the right for an overreaching federal government-an intrusive "nanny state." In 2011, the light bulb standard became front-page news as numerous repeal bills were introduced in Congress and Republican presidential candidates advocated repeal in their stump speeches. This controversy over the light bulb standard may be a harbinger of open conflict over a broader class of product efficiency standards, which have previously been obscure energy policy measures. Below, I explore the larger implications of the light bulb debate.

Congress enacted the first efficiency standards for light bulbs in the Energy Independence and Security Act of 2007 ("EISA"). ${ }^{145}$ The statute required DOE to issue Tier 1 standards mandating a $25 \%$ to $30 \%$ increase in light bulb efficiency, to be phased in for different wattage bulbs between 2012 and 2014, and it required DOE to issue Tier II standards to take effect in 2020 , which would raise light bulb efficiency at least $60 \%{ }^{146}$ Lighting is a major component of U.S. energy consumption. Approximately one hundred large power plants are needed in the United States just to power residential and office

President George H.W. Bush signed the Energy Policy Act of 1992, Pub. L. No. 102-486, 106 Stat. 2776 (codified as amended in scattered sections of Titles 16, 25, 26,30, and 32 of the U.S. Code), and President George W. Bush signed the Energy Policy Act of 2005, Pub. L. No. 109-58, 119 Stat. 594 (codified as amended in scattered sections of Titles 16, 22, 26, and 42 of the U.S. Code) and the Energy Independence and Security Act of 2007, Pub L. No. 110-140, 121 Stat. 1492 (codified in scattered sections of Titles $2,15,42$, and 46 of the U.S. Code).

143. Bill Summary \& Status: 100th Congress (1987 - 1988), S.83, Major Congressional Actions, LIBR. CONGRESS, http://thomas.loc.gov/cgi-bin/bdquery/z?d100:SN00083:@@@ (last visited Aug. 28, 2012).

144. Bill Summary \& Status: 110th Congress (2007 - 2008), H.R.6, Major Congressional Actions, LIBR. CONGRESS, http://thomas.loc.gov/cgi-bin/bdquery/z?d110:HR00006:@@@R (last visited Aug. 28, 2012).

145. Pub. L. No. 110-140, 121 Stat. 1492 (codified at 42 U.S.C. $\$ 6292(2008)$ ).

146. JEFFrey Logan, Cong. RESEARCH SERV., RS22822, Lighting EFFICIENCY STANDARDS IN THE ENERGY INDEPENDENCE AND SECURITY ACT OF 2007, at 2 (2008). 
lighting, ${ }^{147}$ and incandescent bulbs are woefully inefficient in converting electricity into visible light. ${ }^{148}$

In 2009, DOE issued the Tier 1 standard, requiring at least a $25 \%$ increase in the efficiency of various bulbs, beginning with the one hundred-watt light bulb. ${ }^{149}$ This new standard would avoid $\mathrm{CO}_{2}$ emissions equivalent to seventeen million cars. ${ }^{150}$ In the media, the Tier 1 standard was repeatedly mischaracterized as a design standard that banned the 125-year-old incandescent light bulb, ${ }^{151}$ though the standard was in fact a performance standard, not a design standard or a ban. The DOE standard was widely supported by lighting manufacturers, who had negotiated with the agency on its wording and implementation. 152

After the DOE rulemaking, there was a swift reaction against the potential disappearance of Thomas Edison's iconic light bulb. "Let there be incandescent light and freedom. That's the American way," radio commentator Rush Limbaugh said on a broadcast. ${ }^{153}$ Republican presidential candidate Michelle Bachman called for repeal of the standard and promised to allow "you to buy any light bulb you want."154 The Wall Street Journal editorial page described the light bulb standard as a "nanny state" provision "passed at the height of the

147. Id.

148. The overall efficiency of incandescent bulbs is $1.3 \%$. About two-thirds of the energy in coal is lost in generating electricity, about $9 \%$ is lost in transmitting and distributing the electricity, and an incandescent bulb's efficiency in transforming electricity to visible light is only 4\%. In comparison, compact fluorescent lamps (CFLs) are about four times more efficient. A complete switch in the United States from incandescent lighting to CFLs today would save nearly $6 \%$ percent of the total electricity generated in the United States. REAL PROSPECTS REPORT, supra note 1 , at 30 .

149. Energy Conservation Program: Energy Conservation Standards and Test Procedures for General Service Fluorescent Lamps and Incandescent Reflector Lamps, 74 Fed. Reg. 34,080 (July 14, 2009) (codified at 10 C.F.R. $\$ 430.32$ (2012)).

150. See Robert B. Semple, Jr., Dim and Dimmer, N.Y. TIMES, July 10, 2011, at SR11.

151. See Editorial, The Light Bulb Police, WALL ST. J., June 7, 2011, at A16 ("[W]e will all be required to buy compact fluorescent lights, or CFLs."); Led by Murdoch Outlets, Conservative Media Misled Light Bulb Consumers 40 Times In 7 Months, Clmate Progress (July 19, 2011, 9:43 AM), http://thinkprogress.org/romm/2011/07/19/272195/murdoch-conservative-mediamisled-light-bulb-consumers/ (detailing media mischaracterization of the light bulb efficiency standard).

152. NEMA Reiterates That Light Bulb Efficiency Standards Remain, Consumers Retain Diverse Options for Efficient Light Bulbs, NAT'L ELECTRICAL MANUFACTURERS ASS'N (Dec. 16, 2011, 12:00 AM), http://www.nema.org/News/Pages/NEMA-Reiterates-that-Light-BulbEfficiency-Standards-Remain-Consumers-Retain-Diverse-Options-for-Efficient-Light-Bulbs.aspx.

153. Steven Mufson, Light Bulb Standards Won't Be Dimmed by Congress's Action, WASH. PosT, Dec. 17, 2011, at A10.

154. Andrew Restuccia, House Turns Out the Lights on Bulb Bill, HILL, July 13, 2011, at 1. 
global warming fad-scare when all proper thinkers were supposed to sacrifice to the anticarbon gods." 155

Michigan Congressman Fred Upton symbolizes the shift in views in the Republican Party about energy efficiency standards. ${ }^{156}$ Upton was one of the authors of the original 2007 language in the EISA creating the light bulb standard. In a 2007 press release, he claimed:

This common sense, bipartisan approach partners with American industry to save energy as well as help foster the creation of new domestic manufacturing jobs. By upgrading to more efficient light bulbs, we will help preserve energy resources and reduce harmful emissions, all the while saving American families billions of dollars in their electric bills-and the benefits will be as easy as a flip of the switch. ${ }^{157}$

In 2011, however, upon assuming the chairmanship of the House Energy and Commerce Committee, Upton made an abrupt about-face and condemned the standard he had authored. The public, Upton claimed, was sending "a clear signal that markets-not governments—-should be driving technological advancements." 158

By 2011, at least five separate bills had been introduced to repeal the light bulb standard. ${ }^{159}$ On July 12, 2011, the full House voted on repeal, but the bill fell fifty-seven votes short. ${ }^{160}$ Meanwhile,

155. The Light Bulb Police, supra note 151; see also Restuccia, supra note 154 (quoting Sen. Jim DeMint: "It is just another government intrusion in our lives, and in the context of ObamaCare, telling us what kind of health insurance we have to buy, I think people are just increasingly aggravated that the government is telling us what kind of toilets we have, what kind of light bulbs we have, what kind of health insurance, so I think it is just coming to a boil outside.").

156. See Robin Bravender, Conservatives Burn Over Fred Upton's Light Bulb Law, PoLITICo (Nov. 14, 2010, 7:35 AM), http://www.politico.com/news/stories/1110/45059.html (describing criticism from various conservative leaders of energy efficient light bulb standards).

157. Rep. Upton Measure to Upgrade Energy Efficiency Standards for all Light Bulbs Now Law, FED. NEWS SERV., Dec. 19, 2007.

158. Restuccia, supra note 154.

159. See Light Bulb Freedom of Choice Act, H.R. 5616, 110th Cong. (2008) (repealing the 2007 standards unless the Government Accountability Office finds that (1) consumers would obtain a net financial savings by switching to the more efficient bulbs, (2) no health risks would be introduced by the switch, and (3) total U.S. CO2 emissions would decline by $20 \%$ by 2025 as a result of the switch); Light Bulb Freedom of Choice Act, H.R. 849, 112th Cong. (2011) (same); Better Use of Light Bulbs Act, H.R. 6144, 111th Cong. (2010) (repealing the light bulb standards); Better Use of Light Bulbs Act, H.R. 91, 112th Cong. (2011) (same); Better Use of Light Bulbs Act, S. 395, 112th Cong. (2011) (same).

160. The vote on July 12 was on the Better Use of Light Bulbs Act, introduced by Rep. Joe Barton on July 6, 2011. That bill moved to a full floor vote without a hearing. The vote was 233 193 , and a $2 / 3$ vote in favor was required because the vote was on a motion to suspend the rules and pass the bill. Bill Summary \& Status: 112th Congress (2011 - 2012), H.R. 2417, All 
as the repeal legislation was being debated in Congress, manufacturers such as GE, Sylvania, and Phillips were publicly stating that they had already shifted production toward more efficient bulbs due to the Tier 1 standard. ${ }^{161}$ Not only could the manufacturers comply with the new standard through compact fluorescent and LED bulbs, but by 2010, they had also unveiled a new generation of compliant, high-efficiency incandescent bulbs. ${ }^{162}$

The light bulb controversy came to a head in December 2011. As part of a major omnibus spending bill needed to avert a government shutdown, Republicans successfully introduced language that prohibited DOE, for one year, from expending any funds to enforce the new Tier 1 standard, but the spending bill did not repeal the standard. ${ }^{163}$ According to many lighting manufacturers, the oneyear ban on enforcement funding had no effect on their phase out of older incandescents, ${ }^{164}$ and for the time being, the 2007 efficiency standard remains the law.

The skirmish over light bulb efficiency standards offers several lessons for the future of product standards. First, it highlights that standards could become a partisan issue in the United States. Although DOE can proceed with issuance of MEPS for a dozen or more products under existing authority, future Congressional legislation authorizing new MEPS may become controversial. A seesaw effect may emerge in which MEPS are enacted and then threatened with repeal, depending on party control over the different branches of government. Other nations are moving ahead with a variety of energy efficiency measures, so if the federal efficiency program stalls, the already-wide gap between the United States and other countries in per capita energy consumption could grow even larger. ${ }^{165}$

Congressional Actions, LIBR. CONGRESS, http://thomas.loc.gov/cgi-bin/bdquery/z?d112: HR02417:@@@ (last visited Aug. 29, 2012).

161. See LOGAN, supra note 146, at 3 (describing GE's and Phillips's plans for introducing new light bulbs that meet the Tier 1 standards). According to GE, $94 \%$ of its lighting investment was in energy efficient products in 2011, a $28 \%$ increase from 2010 . Mufson, supra note 153.

162. See Vestel, supra note 119 (describing the wave of innovation after the light bulb efficiency standards were enacted).

163. Consolidated Appropriation Act, 2012, H.R. 2055, 112th Cong. $\S 2(\mathrm{~b})$ (2012); Andrew Restuccia, Omnibus Spending Deal Blocks Funding for Light Bulb Efficiency Standards, HILL (Dec. 15, 2011), http://thehill.com/blogs/e2-wire/e2-wire/199851-spending-deal-blocks-light-bulbefficiency-standards.

164. See Mufson, supra note 153.

165. See Sachs, supra note 58, at 300 (comparing countries on per capita energy consumption). 
Second, the light bulb controversy in the United States indicates that the political framing of efficiency policy is shiftingfrom a focus on energy and cost savings to a focus on personal freedom and limiting intrusive government. Given widespread denial of climate change on the right, it will be difficult for any Republican politician to justify efficiency standards on environmental grounds. Even if standards are justified purely as cost-saving measures, rather than as climate change strategy, the cost-saving arguments may be trumped in the future by concerns over intrusive government. ${ }^{166}$

Will this political shift affect products other than light bulbs? It may be too soon to tell, and the political dynamics will likely depend on the product subject to regulation. Other efficiency standards, such as those for refrigerators and air conditioners, have increased efficiency without altering the fundamental characteristics of the product. The light bulb standard, on the other hand, promoted noticeable changes in the product, creating public backlash. Not only did the standard apply to an iconic product, but millions of consumers thought Compact Fluorescent Lamps ("CFLs") were simply not equivalent in hue to the old standby. Therefore, it is unclear whether the backlash on the right against mandatory product standards will spill over into those MEPS that do not create a noticeable impact on the consumer's experience.

What was really at stake in the light bulb controversy were competing conceptions of consumer sovereignty. ${ }^{167}$ The background assumption of opponents was that consumers are sovereign and should be free to make whatever choice they want in the marketplace-even wasteful choices that cost them more money. One official from the Heritage Foundation, for example, pledged that conservatives will continue to seek repeal of energy efficiency mandates that "dictate choice." 168 The background assumption of

166. See Katrina Fischer Kuh, When Government Intrudes: Regulating Individual Behaviors That Harm the Environment, 61 DUKE L.J. 1111, 1175 (2012) ("[Governmental] controls on environmentally significa nt individual behaviors . . . [are] . . particularly vulnerable to claims of government intrusion ....").

167. Consumer sovereignty, a term originally coined by economist William Hutt, refers to the "controlling power exercised by free individuals, in choosing between ends, over the custodians of the communities' resources." W. H. Hutt, The Concept of Consumers' Sovereignty, 50 ECON. J. 66, 66 (1940); see also Kysar, supra note 93, at 584-87 (arguing that consumer sovereignty encompasses consumer preferences for how products are made). See generally $\mathrm{H}$. Spencer Banzhaf, Consumer Sovereignty in the History of Environmental Economics, 43 HIST. POL. ECON. 339 (2011) (outlining how competing visions of consumer sovereignty have shaped cost-benefit analysis and environmental policy).

168. Restuccia, supra note 154. 
supporters, on the other hand, was that consumers' choices for items as simple as a light bulb have wider implications for the national and global environments. Externalities turn private choices into public risks. While opponents of the standard focused on the freedom of each consumer to choose, supporters were drawing back the lens to focus on the environmental implications of billions of individual decisions to buy inefficient light bulbs.

Looking forward, supporters of product standards as climate policy should forthrightly acknowledge that every product regulationincluding energy efficiency standards, air bag requirements for cars, and safety standards for baby cribs-dictates consumer choice to some extent. The noncompliant products are not available as a consumer choice in the marketplace. A limitation on consumer choice in the marketplace is not per se suspect. The relevant question is whether the limitation on consumer choice sufficiently promotes national interests in public health, safety, and environmental protection.

Scholars are beginning to question the sacrosanct role of consumer sovereignty as the primary driver of economic and environmental policy. Consumer preferences have traditionally been viewed as exogenous to market activity-the ex ante source of desire that shapes how consumers act in the marketplace. The role for both the market and for law was to ensure maximal satisfaction of these preferences.169 But because the climate crisis is, in the end, a crisis of unsustainable consumption, this traditional vision of consumer sovereignty has now become highly problematic-an obstacle to avoiding dangerous climate disruption. If climate change mitigation policy is going to reach beyond large industrial sources of emissions, policymakers will continually confront this traditional conception of consumer sovereignty. Indeed, the fight over light bulb efficiency standards could be just a preview of larger battles to come as nations begin to address the climate consequences of individual and household behavior.

Extensive social science and marketing research has demonstrated that the traditional view of consumer sovereignty is inaccurate. Consumer preferences for products are not exogenous to market activity. Rather, consumer preferences are powerfully constructed-by advertising and packaging, certainly-and also by neighborhood and community norms and by law itself. ${ }^{170}$ For example, the preference of many consumers for incandescent bulbs over CFLs or

169. Kysar \& Vandenbergh, supra note 15, at 10829.

170. Id. at $10829-30$. 
newer LED bulbs has been shaped by habit, history, and the fact that existing law allows for the complete externalization of the environmental costs of wasteful energy consumption. Though many consumers prefer incandescent bulbs given this cultural and legal backdrop, policymakers should not view that preference as a trump card that prohibits enactment of cost-effective, climate-friendly efficiency standards, or as a trump card that commands repeal of existing standards. According to Michael Vandenbergh and Doug Kysar, arguments that a policy is suspect if it interferes with consumer preferences "miss the subtlety and complexity of individuals' attempts to navigate the dense economy of signs and meanings that is interlaced within the market, right alongside its economy of goods and services." 171 Given the extensive research on how consumer preferences are constructed both through culture and through law, Vandenbergh and Kysar contend, "a great deal more government intervention into consumer product markets on account of environmental impacts of consumption could be justified as a matter of theory."172

This critique of a slavish governmental obeisance to existing consumer preferences may help, in the long run, to bolster the theoretical groundwork for efficiency regulation. But in the near term, as a practical matter to maintain political support for product efficiency regulation, policymakers and energy efficiency advocates still need to make the case for why energy efficiency standards benefit consumers. This argument need not be phrased in terms of global externalities, climate change, or consumer sovereignty. Rather, the message to the public should be that saving fossil fuels is a better, cheaper option than burning them.

\section{CONCLUSION}

Product standards have resulted in dramatic energy savings and should continue to play an important role in climate change mitigation strategy. While environmental law scholars have focused on the major pollution-control statutes, product regulation has been making a significant dent in global pollution-quietly and indirectly-

171. Id. at 10830; see also Vandenbergh \& Steinemann, supra note 15, at 1705 (noting that individuals are strongly influenced by what they perceive to be the behavior of others, and if "carbon-reducing behaviors are perceived as widespread ... more people are likely to adopt them").

172. Kysar \& Vandenbergh, supra note 15 , at 10830 . 
through shaping the eco-footprint of energy-consuming products in the marketplace. Product standards are not a panacea for climate change, and standing alone they will not reduce global energy demand. But standards are an effective solution for one piece of the mitigation puzzle: driving efficiency improvements in billions of consumer goods. Designed correctly, with sensitivity to the capabilities of industry and the preferences of consumers, MEPS can lead to cost-effective energy efficiency gains-the lowest of the low-hanging fruit in climate policy. 